\title{
Identification of four novel phosphorylation sites in estrogen receptor $\alpha$ : impact on receptor-dependent gene expression and phosphorylation by protein kinase CK2
}

\author{
Christopher C Williams ${ }^{1}$, Aninda Basu ${ }^{2}$, Abeer El-Gharbawy ${ }^{2}$, \\ Latonya M Carrier ${ }^{2}$, Carolyn L Smith ${ }^{3}$ and Brian G Rowan*2
}

Address: ${ }^{1}$ Division of Basic Pharmaceutical Sciences, College of Pharmacy, Xavier University of Louisiana, New Orleans, LA, USA, ${ }^{2}$ Department of Structural and Cellular Biology, Tulane University School of Medicine, New Orleans, LA, USA and ${ }^{3}$ Department of Molecular and Cellular Biology, Baylor College of Medicine, Houston, TX, USA

Email: Christopher C Williams - cwillia0@tulane.edu; Aninda Basu - aninda_bose@rediffmail.com; Abeer El-Gharbawy - reeba7@hotmail.com; Latonya M Carrier - Icarrie@tulane.edu; Carolyn L Smith - carolyns@bcm.tmc.edu; Brian G Rowan* - browan@tulane.edu

* Corresponding author

Published: 31 December 2009

BMC Biochemistry 2009, 10:36 doi:10.1186/147|-2091-10-36
Received: 22 January 2009

Accepted: 31 December 2009

This article is available from: http://www.biomedcentral.com//47I-209|//0/36

(c) 2009 Williams et al; licensee BioMed Central Ltd.

This is an Open Access article distributed under the terms of the Creative Commons Attribution License (http://creativecommons.org/licenses/by/2.0), which permits unrestricted use, distribution, and reproduction in any medium, provided the original work is properly cited.

\begin{abstract}
Background: Estrogen receptor $\alpha(E R \alpha)$ phosphorylation is important for estrogen-dependent transcription of ER-dependent genes, ligand-independent receptor activation and endocrine therapy response in breast cancer. However ER $\alpha$ phosphorylation at the previously identified sites does not fully account for these receptor functions. To determine if additional ER $\alpha$ phosphorylation sites exist, COS-I cells expressing human $E R \alpha$ were labeled with ${ }^{32} \mathrm{P}^{2} \mathrm{H}_{3} \mathrm{PO}_{4}$ in vivo and $\mathrm{ER} \alpha$ tryptic phosphopeptides were isolated to identify phosphorylation sites.
\end{abstract}

Results: Previously uncharacterized phosphorylation sites at serines 46/47, 282, 294, and 559 were identified by manual Edman degradation and phosphoamino acid analysis and confirmed by mutagenesis and phospho-specific antibodies. Antibodies detected phosphorylation of endogenous ER $\alpha$ in MCF-7, MCF-7-LCC2, and Ishikawa cancer cell lines by immunoblot. Mutation of Ser-282 and Ser-559 to alanine (S282A, S559A) resulted in ligand independent activation of ER $\alpha$ as determined by both ERE-driven reporter gene assays and endogenous pS2 gene expression in transiently transfected HeLa cells. Mutation of Ser-46/47 or Ser-294 to alanine markedly reduced estradiol dependent reporter activation. Additionally protein kinase CK2 was identified as a kinase that phosphorylated ER $\alpha$ at S282 and S559 using motif analysis, in vitro kinase assays, and incubation of cells with CK2 kinase inhibitor.

Conclusion: These novel ER $\alpha$ phosphorylation sites represent new means for modulation of ER $\alpha$ activity. S559 represents the first phosphorylation site identified in the extreme C-terminus (F domain) of a steroid receptor.

\section{Background}

$\mathrm{ER} \alpha$ is a member of the nuclear receptor superfamily of transcription factors whose activity is primarily regulated by the binding of small lipophilic ligands. Estradiolinduced ER $\alpha$ signaling is indispensable for many physiological processes including reproductive tissue develop- 
ment (uterus, mammary gland, and ovary), bone metabolism, and immune, cardiovascular, and neurological function(1-3). Importantly, ER $\alpha$ has remained the primary pharmacological target for endocrine therapy of $\mathrm{ER} \alpha$ positive breast cancer. Selective estrogen receptor modulators (SERMs) such as tamoxifen, as well as estrogen ablation are front line therapies for the treatment of ER $\alpha$-expressing breast neoplasias.

Various aspects of ER $\alpha$ transcriptional activation are dependent on phosphorylation of the receptor. Coactivator recruitment, subcellular localization, receptor dimerization, ligand binding, and posttranslational modifications are regulated through the phosphorylation of individual sites of ER $\alpha$. Nine ER $\alpha$ phosphorylation sites have been functionally characterized to date: serines 102 (S102), 104 (S104), 106 (S106), 118 (S118), and 167 (S167) in the AF-1 domain; serine 236 (S236) in the DNA binding domain; and serines 305 (S305), threonine 311 (T311), and tyrosine 537 (Y537) in the AF-2/ligand binding domain (LBD) (Figure 1). The functional interaction of ER $\alpha$ with coregulator proteins such as $\mathrm{CBP} / \mathrm{p} 300$ and the p160 family of coactivators is regulated by phosphorylation of ER $\alpha$ in the AF-1 domain [1-4]. S118 is phosphorylated in response to both estradiol and epidermal growth factor through CDK7 and ERK1/2 dependent pathways, respectively $[5,6]$. Phosphorylation of S118 in conjunction with S104 and S106 mediates ligand independent activation of ER $\alpha$ by facilitating functional ER $\alpha$ interactions with the transcriptional coactivators CBP and SRC-1 [3]. It has also been demonstrated that glycogen synthase kinase 3 (GSK-3) can mediate phosphorylation of S102, S104, S106, and S118 in vivo and vitro, where S102 phosphorylation is dependent on pS104 [7]. S167 of ER $\alpha$ is also phosphorylated in response to epidermal growth factor receptor signaling through p90 RSK (p90 ribosomal S6 kinase), thereby significantly enhancing $\mathrm{ER} \alpha$ transcriptional activity [8]. This laboratory demonstrated that src kinase dependent activation of AKT resulted in phosphorylation of ER $\alpha$ at $\mathrm{S} 167$ and this site was necessary for src mediated $\mathrm{ER} \alpha$ transcriptional activity [4]. Additionally, protein kinase CK2 which is upregulated in most proliferating tissues, phosphorylates S167 and regulates interaction of ER $\alpha$ with estrogen response elements (ERE) in vitro $[9,10]$.

In addition to phosphorylation sites that have been functionally characterized, recent studies have identified novel phosphorylation events at sites S102, S154, S212, S294, S554, and S559 by mass spectrophotometry [11,12]. Concurrent studies described herein have confirmed S294 and S559 as bona fide ER $\alpha$ phosphorylation sites using phospho-peptide mapping and have ascribed the initial functional significance of these sites to ER $\alpha$ transcriptional activity. Additionally, antibodies utilized within this study have detected in vivo phosphorylation of S282, S294, and S559 in immunohistochemical analysis of human breast carcinoma tissue microarrays [13].

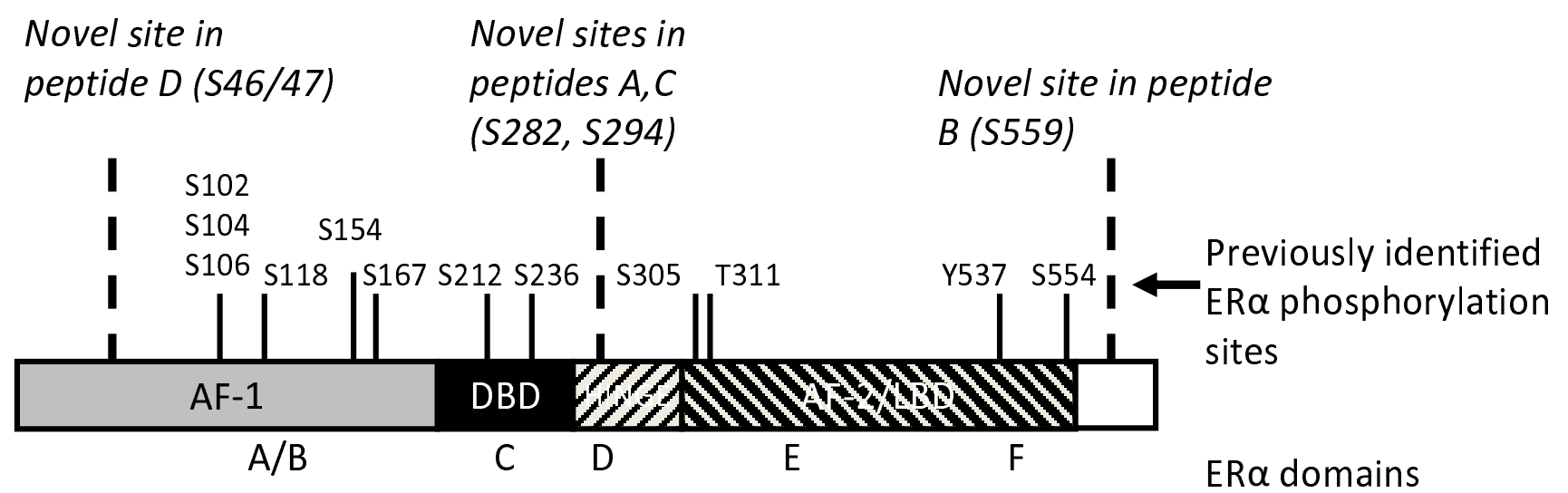

Figure I

Estrogen receptor $\alpha(E R \alpha)$ phosphorylation sites. The schematic in Figure I depicts both previously identified and novel $\mathrm{ER} \alpha$ phosphorylation sites with relative locations within the ER $\alpha$ functional domains. Serines I04, I06, II8, and I67 constitute phosphorylation sites within the ligand-independent activation function-I (AF-I) domain of ER $\alpha$. S236 is the first phosphorylation site within the DNA binding domain of ER $\alpha$. Serine 305, threonine 3 II and tyrosine 537 are phosphorylation sites identified within the ligand-dependent activation function-2 (AF-2) domain. Indicated in bold italicized type are newly characterized phosphorylation sites of ER $\alpha$ : S46/47, S282, S294 and S559. S46/47 constitutes an additional site of phosphorylation within the AF-I domain. Serines 282 and 294 are located in the hinge domain of ER $\alpha$ proximal to the DNA binding domain. Of note, S559 is the first phosphorylation site identified in the extreme C-terminal F domain of ER $\alpha$ and other steroid receptors. SI54, S2I2, S294, S554, and S559 have been recently identified or independently confirmed by mass spectrophotometry (I I). 
Until recently, evidence for a role of $E R \alpha$ phosphorylation in breast cancer had been extrapolated from breast cancer cell line models. However, recent studies demonstrate that ER $\alpha$ phosphorylation may significantly impact ER $\alpha$ signaling in human tissues. Immunohistochemical studies have demonstrated S118 phosphorylation of ER $\alpha$ in breast cancer patient biopsies [6,14]. S118 phosphorylation was associated with improved disease free survival despite the ability of S118 phosphorylation to mediate ligand independent $\mathrm{ER} \alpha$ function and association of S118 phosphorylation with EGFR signaling, a known contributor to tamoxifen resistance in tissue culture models $[15,16]$. Furthermore, S118 phosphorylation was directly associated with tamoxifen sensitivity as well as with a more highly differentiated tumor phenotype $[17,18]$. Another study, however, found that ER $\alpha$ S118 phosphorylation was related to Her2 expression and tamoxifen resistance upon patient relapse [19]. S167 phosphorylation has also been correlated to responsiveness to endocrine therapy as well as increased disease free and overall survival in breast cancer patients [20]. Interestingly, S167 is downstream of AKT signaling which has been associated with tamoxifen resistance and agonist activity in endometrial cancer cells [4]. Most recently, it has been reported that low levels of S118 phosphorylation accompanied by high levels of S167 phosphorylation were associated with increased overall survival and disease-free survival in a study of breast cancer patient biopsies [21]. Furthermore it was recently suggested that phosphorylation of serine 305 in premenopausal women with breast cancer was related to tamoxifen resistance [22]. Although the number of clinical studies correlating ER $\alpha$ phosphorylation and patient prognosis/outcome are relatively few, these studies present the possibility that ER $\alpha$ phosphorylation could be predictive of responsiveness to endocrine therapy in $\mathrm{ER} \alpha$ positive breast cancer.

A number of reports indicate that the most studied of the previously identified ER $\alpha$ phosphorylation sites are not the critical targets of signaling pathways that regulate the relative antagonist or agonist properties of tamoxifen. Three N-terminal serine phosphorylation sites (S104, S106, S118) in ER $\alpha$ were shown to be necessary, but not sufficient for growth factor potentiation of liganddependent activation and ligand-independent activation of the ER $\alpha$ [5,23-25]. Of significance from these studies was the recognition that at least three otherER $\alpha$ serine phosphorylation sites remained to be identified in vivo.

With the expectation that additional ER $\alpha$ phosphorylation sites may play a primary role in the modulation of $E R \alpha$ function, the present study sought to identify novel $\mathrm{ER} \alpha$ phosphorylation sites employing in vivo labeling of mammalian cells with $\left[\mathrm{P}^{32}\right] \mathrm{H}_{3} \mathrm{PO}_{4}$, phosphopeptide mapping and biochemical identification of sites. The present study has identified four novel ER $\alpha$ phosphorylation sites in vivo at serine residues S46/47, 282, 294, and 559. The identification and characterization of these novel ER $\alpha$ phosphorylation sites will provide further insight into ER $\alpha$ function in both normal and disease states.

\section{Results \\ Identification of serines 47, 282, 294, and 559 as novel ER phosphorylation sites}

To identify hitherto unidentified ER $\alpha$ phosphorylation sites, the present study employed the same approach used by this laboratory to identify phosphorylation sites in coactivator SRC-1 [26]. Briefly, COS-1 cells expressing $\mathrm{ER} \alpha$ were labeled in vivo, with $\left[\mathrm{P}^{32}\right] \mathrm{H}_{3} \mathrm{PO}_{4}$ and $\mathrm{ER} \alpha$ was immunopurified and fractionated by SDS-PAGE. A small aliquot was used to confirm purification of ER $\alpha$ (Figure $2 \mathrm{~A})$. Following autoradiography of the wet gel, the $67 \mathrm{Kd}$ band corresponding to ER $\alpha$ was excised, subjected to tryptic digestion, and ER $\alpha$ tryptic peptides were separated on a C-18 reverse-phase HPLC column using a $0-45 \%$ acetonitrile gradient. Radiolabeled peptides were collected and electrophoresed on a $40 \%$ alkaline acrylamide gel and autoradiographed to reveal sites of $\mathrm{P}^{32}$ incorporation corresponding to ER $\alpha$ phosphorylation (Figure 2B). Subsequently, phosphopeptides were subjected to phosphoamino acid analysis and modified manual Edman degradation to determine the position of each phosphoamino acid within the phosphopeptides. Data was obtained for individual phosphopeptides isolated from HPLC fractions or alkaline polyacrylamide gels containing each of the four major phosphopeptides labeled A-D in Figure 2B. Phosphoamino acid analysis indicated that each phosphopeptide contained only phospho-serine (Figure 2C). Modified manual Edman degradation determined the position of $\mathrm{P}^{32}$ phosphorylated amino acids within each phosphopeptide as follows: phosphopeptide $\mathrm{A}, \mathrm{P}^{32}$ release at cycle 5; phosphopeptide $\mathrm{B}, \mathrm{P}^{32}$ release at cycle 4; phosphopeptide $\mathrm{C}$, $\mathrm{P}^{32}$ release at cycle 7, and; phosphopeptide $\mathrm{D}, \mathrm{P}^{32}$ release at cycle 10 (Figure 2D). Comparison of these results to the predicted tryptic peptides of ER $\alpha$ revealed a single candidate phosphopeptide for phosphopeptide A and for phosphopeptide B (Table 1 ). The phosphorylation site in phosphopeptide A was identified as serine 282 and the site in phosphopeptide B was identified as serine 559. S559 phosphorylation has been recently reported by Atsriku et al. through MALDITOF mass spectrophotometry in ER $\alpha$ MCF-7 cells, thereby validating that $\mathrm{S} 559$ is a phosphorylation site for $\mathrm{ER} \alpha$ [11]. For phosphopeptide C there were four candidate peptides predicted to have a cycle 7 serine release by manual Edman degradation (Table 1). S294 was a predicted substrate for Ser/Pro directed kinases and this sequence is conserved among nuclear receptors (see Table 2). Two of the other three candidates for phosphopeptide 


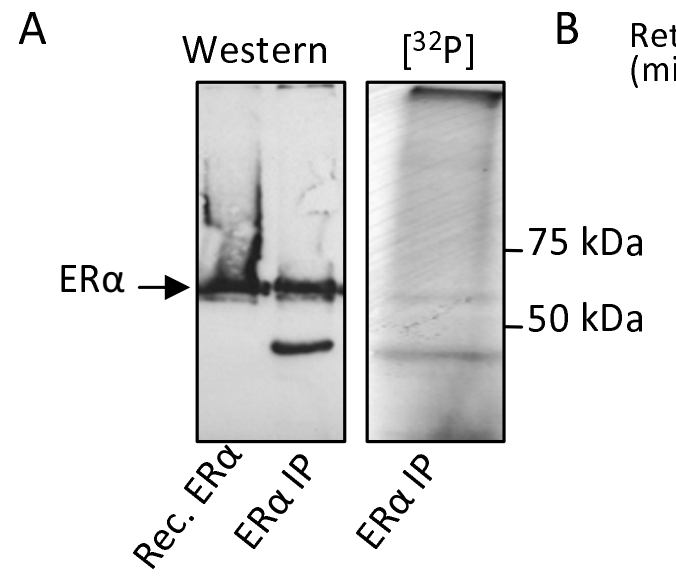

D

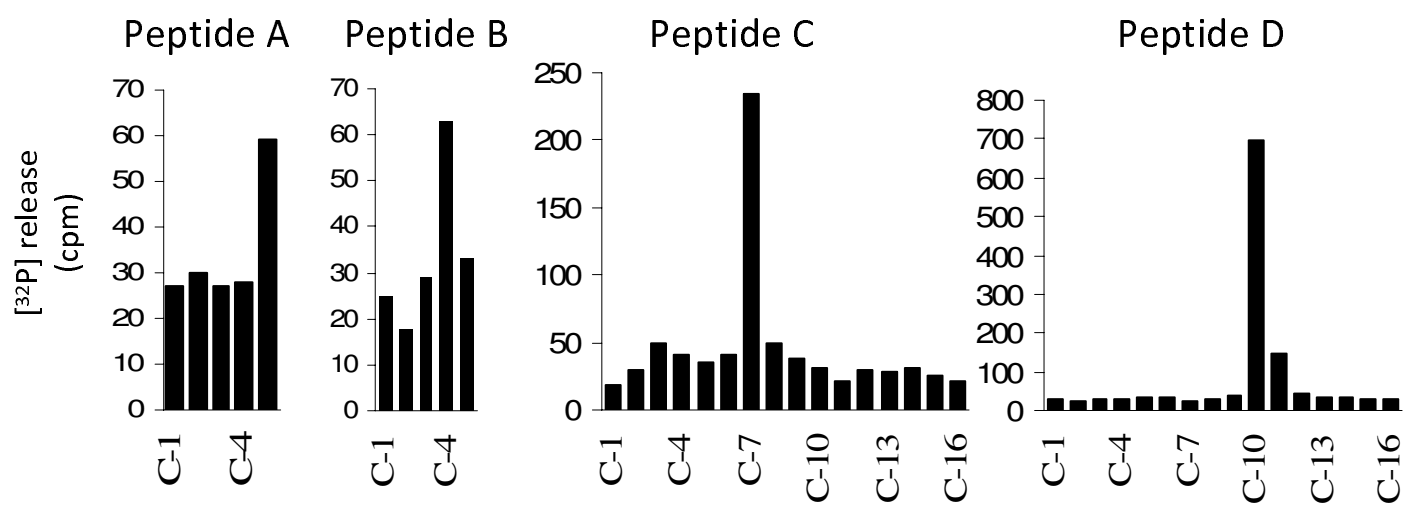

\section{Figure 2}

Identification of ER $\alpha$ phosphorylated at serine residues 47, 282, 294 and $559.6 \times 10^{8}$ COS-I cells were cultured in phenol red free DMEM supplemented with $10 \%$ charcoal stripped FBS. Cells were transfected with wt ER $\alpha$ expression plasmid as noted in materials and methods. 24 hours post-transfection, cells were phosphate-depleted and medium was exchanged with phosphate free DMEM supplemented with $\mathrm{I} \%$ dialyzed $\mathrm{FBS} .4 \mathrm{mCi}\left[\mathrm{P}^{32}\right] \mathrm{H}_{3} \mathrm{PO}_{4}$ and $\mathrm{I0}^{-8} \mathrm{M}$ estradiol were added to each plate and incubated overnight. Cells were subjected to denaturing lysis, ER $\alpha$ purified by immuno-affinity column, eluted, and fractionated by SDS-PAGE. (A) The band corresponding to the $67 \mathrm{kDa}$ ER $\alpha$ was excised and subjected to tryptic digestion. Tryptic ER $\alpha$ peptides were separated by reverse phase HPLC using a C-I 8 column and $0-45 \%$ acetonitrile gradient over 90 minutes. (B) Fractions were collected, pooled according to HPLC retention times and electrophoresed on $40 \%$ acrylamide alkaline peptide gels. Gels were autoradiographed, revealing distinct ER $\alpha$ phosphopeptides. 4 novel phosphopeptides (A, B, C, and $D)$ resulting from tryptic digestion of ER $\alpha$ were identified. Each phosphopeptide was then excised, and subjected to modified manual Edman degradation (MED) and phosphoamino acid analysis as described in Materials and Methods. (C) Phosphoamino acid analysis revealed that the phosphopeptide $A, B, C$ and $D$ contained only phosphoserine. Representative phosphoamino acid analyses autoradiograms are presented with identical results detected for phosphopeptides A, B, C, and D. (D) MED detected ${ }^{32} \mathrm{P}$ release for phosphopeptides A-D. Combined data for phosphoamino acid analysis and MED is presented in Table I.

C were not predicted to be phosphorylation sites according to NetPhosK phosphorylation prediction models [27]. The fourth candidate, S527, was a predicted substrate for PKC but the sequence is not conserved among nuclear receptors. Therefore of the four candidate phosphopeptides, S294 was the most likely candidate for the phosphorylated residue contained within peptide C. As with S559, S294 has recently been confirmed as a ER $\alpha$ phosphorylation site by MALDI-TOF mass spectrophotometry in MCF-
7 cells [11]. Similarly for phosphopeptide D, two possible peptides were predicted to have a cycle 10 serine release by manual Edman degradation; either S47 or S193. S47 was contained in an imperfect consensus sequence for PKC whereas S193 was not within a predicted kinase recognition sequence (Table 1).

To distinguish among the candidate peptides for phosphopeptides $\mathrm{C}$ and $\mathrm{D}$, and to provide further confirma- 
Table I: Identification of novel ER $\alpha$ phosphorylation sites.

\begin{tabular}{|c|c|c|c|c|c|c|}
\hline Peptide & Amino acid & MED Cycle & Candidate phosphopeptides & Identity & Verified by mutagenesis & Phospho- antibody \\
\hline $\mathbf{A}$ & Serine & 5 & 278-GEVG (S) AGDMR-287 & Serine 282 & + & + \\
\hline B & Serine & 4 & $\begin{array}{l}\text { 556-GGA (S) } \\
\text { VEETDQSHLATAGSTSSHSLQK-58I }\end{array}$ & Serine 559 & + & + \\
\hline C & Serine & 7 & $\begin{array}{l}\text { I72-GSMAME (S) AK-I80 } \\
\text { 288-AANLWP (S) PLMIK-299 } \\
\text { 450-SIILLN(S)GVYTFLSSTLK-467 } \\
\text { 52I-GMEHLY(S)MK-529 }\end{array}$ & Serine 294 & + & + \\
\hline D & Serine & 10 & $\begin{array}{l}\text { 38-PLGEVYLDS (S) } \\
\text { KPAVYNYPEGAAYEFNAAAA } \\
\text { ANAQVYGQTGLPYGPGSEAAAFGSNGL } \\
\text { GGFPPLNSV(S)P(S)PLMLLHPPPQL (S) } \\
\text { PFLQPHGQQVPYYLENE } \\
\text { PSGYTVR-I42 } \\
\text { I84-YCAVCNDY (S) } \\
\text { GYHYGVWSCEGCK-206 }\end{array}$ & Serine 47 & + & - \\
\hline
\end{tabular}

tion of the identity of all phosphorylation sites in phosphopeptides A-D, serine to alanine mutant ER $\alpha$ expression constructs were generated at sites S47, S282, S294, and S559 (S47A, S282A, S294A, S559A). ERo mutants were expressed in COS-1 cells and P32phosphopeptide maps were prepared and compared to phosphopeptide maps of wild-type (wt) ER $\alpha$ (Figure 3A-E). Phosphopeptide maps of S294A or S559A resulted in specific loss of phosphopeptides $\mathrm{C}$ and $\mathrm{B}$, respectively (Figure 3B-C). The phosphopeptide map of S47A resulted in reduced intensity but not complete loss of phosphopeptide D (Figure 3D). A close examination of the first tryptic cleavage site directly C-terminal to $\mathrm{S} 47$ revealed a lysine-proline sequence at residues 48-49. Trypsin cleaves inefficiently at $\mathrm{R} / \mathrm{K}$-proline sequences making it possible that phosphopeptide $\mathrm{D}$ was the result of an incomplete tryptic digest [28]. The next trypsin cleavage site following an incomplete digest at K48 occurs at residue R142 and digestion at this site would result in a very large phosphopeptide of 110 amino acids. The possibility of an incomplete tryptic digest at K48 was consistent with the relative migration of phosphopeptide $\mathrm{D}$ at the top of the alkaline acrylamide gel, and the elution of this phosphopeptide in the later fractions from the $\mathrm{C} 18$ reversed phase column (25). Since the previously identified ER $\alpha$ phosphorylation sites S104, S106, and S118 would also be present in the very large phosphopeptide resulting from incomplete digestion of K48, an ER $\alpha$ expression plasmid was constructed containing four serine-to- alanine mutations at S47, S104, S106, and S118 and a phosphopeptide map of this protein was prepared. As shown in Figure 3E, S47A/S104A/S106A/S118A resulted in complete loss of phosphopeptide D consistent with the interpretation that all four phosphorylation sites S47, S104, S106, and S118 were present in phosphopeptide D. Additionally, it was noted that phosphopeptide C was diminished upon mutation of S104, S106, S47 and S118, suggesting that S294 phosphorylation, or a site within a peptide which co-migrates electrophoretically with peptide $\mathrm{C}$ may be dependent upon phosphorylation of one or several sites within the D peptide (Figure 3D and 3E).

Despite multiple attempts, phosphopeptide maps of S282A consistently resulted in a very weak steady state $\mathrm{ER} \alpha$ phosphorylation profile. This was likely the result of estradiol induced loss of S282A protein after 24 hours (Figure 3F). This effect was time dependent since estradiol did not reduce S282A protein after 3 hours incubation. The destabilization of ER $\alpha$ by mutation of S282A is currently under investigation. The effect of phosphorylation site mutation on phosphorylation at other sites is also under investigation.

\section{Phospho-specific antibodies recognize ER $\alpha$ phosphorylated at serines 282, 294, and 559}

To further verify the authenticity of the phosphorylation sites identified by the biochemical approaches above and to study the impact of ER $\alpha$ phosphorylation at S47, S282,

Table 2: Consensus kinase recognition sequences for novel ER $\alpha$ phosphorylation sites

\begin{tabular}{clll}
\hline Phosphorylation site & Sequence & Consensus recognition site & Putative Kinase \\
\hline Serine 47 & YLD-(S)-(S)K-PAV & $(\mathbf{S} / T)-X-R / K$ & PKC? (imperfect) \\
Serine 282 & GEVG-(S)AGD-M & (S/T)-X-X-E/D & CK2 \\
Serine 294 & NLWP-(S)P-LMI & $(\mathbf{S} / T)-P$ & Proline-directed kinase \\
Serine 559 & RGGA-(S)VEE-T & $(\mathbf{S} / T)-X-X-E / D$ & CK2 \\
\hline
\end{tabular}


A. wtER $\alpha$

Ret. time (min.)
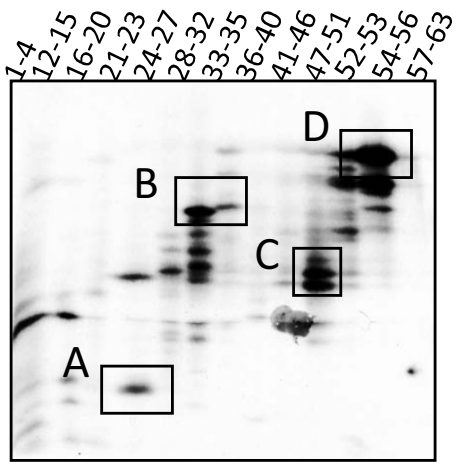

B. $S 294 \mathrm{~A}$

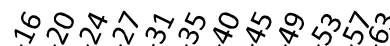

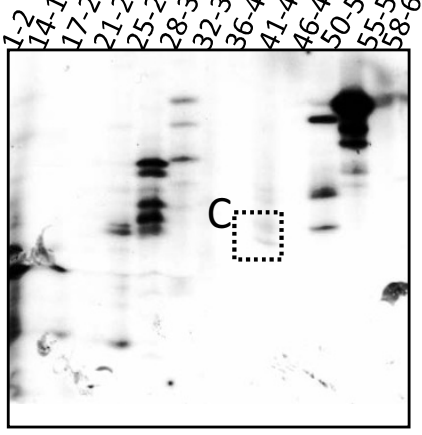

D. S47A

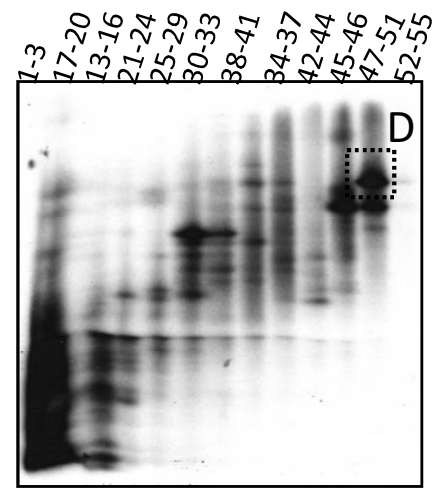

Ret. time

(min.)
E. S47A/S104A/S106A/S118A
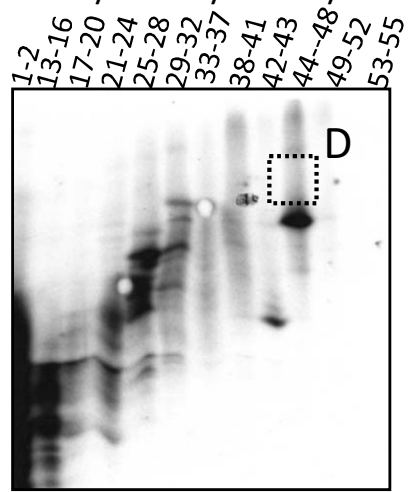

C. S559A

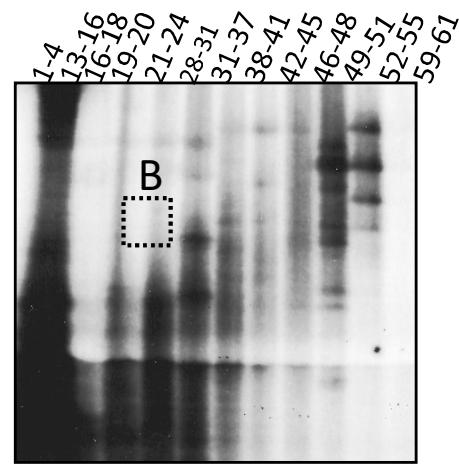

F. S282A

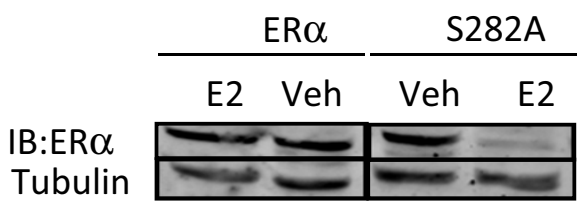

Figure 3

Mutation of serine residues to alanine eliminates specific phosphorylation of peptides. To confirm the identity of phosphorylated serine residues within peptides $A, B, C$, and $D$, serine to alanine mutations were introduced into wt ER $\alpha$ (S47A, S282A, S294A, or S559A). I 2 plates of COS-I cells $\left(4 \times 10^{7} /\right.$ plate) were transfected with $500 \mathrm{ng} / \mathrm{plate}$ of wt ER $\alpha$, S47A, S282A, S294A, or S559A expression plasmids. 18 hours post-transfection, cells were phosphate-depleted, labeled with $4 \mathrm{mCi}$ $\left[{ }^{32} \mathrm{P}\right] \mathrm{H}_{3} \mathrm{PO}_{4}$ and incubated with $10^{-8} \mathrm{M}$ estradiol overnight. ER $\alpha$ was immunopurified and tryptic peptides were separated by HPLC using a C- 18 reversed phase column. Fractions were collected and electrophoresed on a $40 \%$ alkaline polyacrylamide gel followed by autoradiography. (A) Peptide map of wt ER $\alpha$ displaying 4 novel phosphopeptides A-D. (B) S294A resulted in loss of peptide C. C) S559A resulted in loss of peptide B. (D) S47A resulted in a modest decrease in peptide D compared to wt ER $\alpha$. E) S47A/SI 04A/SI 06A/SI I 8A resulted in loss of peptide D. (F) Mutation of S282 to alanine reduces ER $\alpha$ protein following $24 \mathrm{~h}$ incubation with estradiol. $10^{6} \mathrm{COS}-\mathrm{I}$ monkey embryonic kidney cells which had been cultured in phenolred free DMEM supplemented with $10 \%$ fetal bovine serum were transfected with $2.5 \mu \mathrm{g}$ of wt ER $\alpha$ or S282A expression plasmid. 24 hours after transfection, cells were incubated with vehicle (veh) or estradiol (10-8M) for an additional 24 hours. Cell lysates were collected and ER $\alpha$ protein levels determined, using $\alpha$-tubulin as a loading control.

S294, and S559, phospho-specific antibodies to each site were generated. Immunogens (phosphorylated peptides) were designed and rabbit polyclonal antibodies were generated against each phosphorylation site as previously described by this laboratory [29]. To validate the phospho-specific antibodies, S47A, S282A, S294A or S559A were expressed in COS-1 cells and lysates were subjected to Western immunoblotting with total ER $\alpha$ antibody and with phospho-specific antibodies to each site (Figure 4A). Each point mutation was expressed at comparable levels to wt ER $\alpha$. Each phospho-specific antibody recognized wt $\mathrm{ER} \alpha$ but the phospho-specific antibodies to sites S282,
S294 and S559 did not recognize the corresponding mutations S282A, S294A, and S559A confirming that phosphorylation at these sites was necessary for the immuno-reactivity. In contrast, mutation S47A was still recognized by the phospho-antibody to pS47. Of interest was the decreased electrophoretic mobility of ER $\alpha$ upon mutation of $\mathrm{S} 47$ to alanine (Figure 5C). This reduced mobility may be indicative of further post-translational modifications that are regulated by $\mathrm{S} 47$ phosphorylation similar to what has been observed for S305A mutations (27). 
A

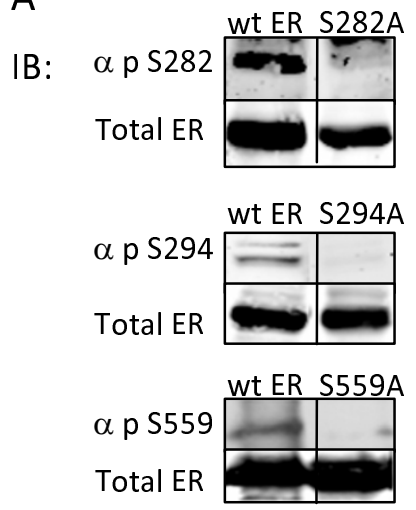

B

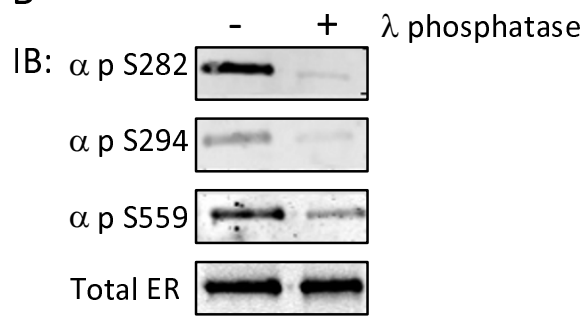

\section{Figure 4}

Confirmation of the specificity of ER phospho-antibodies. (A) Serine to alanine mutations at ER $\alpha$ phosphorylation sites inhibit reactivity of phospho-specific antibodies. COS-I cells cultured in DMEM growth supplemented with I0\% FBS were transiently transfected with $500 \mathrm{ng}$ of either wt ER $\alpha$ or serine to alanine substituted ER $\alpha$ expression plasmids (S47A, S282A, S294A, or S559A). 18 hours post-transfection, cells were lysed and subjected to Western immunoblot analysis utilizing custom polyclonal antibodies directed toward the individual phosphorylated ER $\alpha$ residues (S47, S282, S294, or S559) or monoclonal ER $\alpha$ antibody as indicated. $\alpha$-p-S282, $\alpha$-p-S294, or $\alpha$-p-S559 antibodies did not recognize S282A, S294A, or S559A, respectively, indicating phospho-antibody specificity. Mutation of S47 failed to eliminate immunoreactivity of $\alpha p-S 47$. (B) In vitro $\lambda$ phosphatase treatment of ER $\alpha$ inhibits immunoreactivity of ER $\alpha$ phospho-antibodies. Baculovirus expressed ER $\alpha$ was subjected to dephosphorylation by $\lambda$ phosphatase for 30 minutes at $30^{\circ} \mathrm{C}$ and analyzed by Western immunoblot with antibodies against p-S282, p-S294, p-S559, and total ER $\alpha$. Dephosphorylation inhibited immunoreactivity of, $\alpha-p-S 282, \alpha-p-S 294$, and $\alpha-p-$ S559 without impacting immunoreactivity of total ER $\alpha$ antibody.

To further validate the specificity of the ER $\alpha$ phospho-specific antibodies, baculovirus expressed recombinant ER $\alpha$ was incubated with and without $\lambda$-phosphatase followed by Western blotting with phospho-specific antibodies. Each antibody was determined to be phosphorylation state specific as evidenced by the lack of immunoreactivity following incubation with $\lambda$-phosphatase (Figure 4B).

The results for $\alpha$-pS47 were inconclusive since mutation of this residue failed to inhibit immunoreactivity, yet dephosphorylation by $\lambda$ phosphatase indeed decreased immunoreactivity (data not shown). These findings lend evidence to the existence of an alternative phosphorylation site within the region corresponding to the immunogenic peptide used to generate the pS47 antibody. It was therefore investigated whether phosphorylation of the adjacent serine 46 (S46) was responsible for the immunoreactivity of the $\alpha-p-S 47$ antibody. Results indicate that mutation to alanine of either S46, S47 or S46/S47 did not block immunoreactivity of the p-S47 antibody to ER $\alpha$ (data not shown) indicating that the $\alpha$-p-S47 antibody was not specific for the Western blotting procedure. As such, the $\alpha$-pS47 antibody was not used for subsequent studies. It is possible this antibody may demonstrate specificity in other procedures (e.g. IHC) and this is currently being investigated.

\section{Endogenously expressed ER $\alpha$ is phosphorylated at S282, S294, and S559}

To determine whether endogenously expressed ER $\alpha$ was phosphorylated at sites S282, S294, and S559, ER $\alpha$ was first immunoprecipitated using phosphospecific antibodies directed towards p-S282, p-S294, and p-S559, followed by Western blotting with antibody to total ER $\alpha$ in a panel of $E R \alpha+$ breast cancer cell lines. Using this approach, phosphorylation at each site was detected in MCF-7 breast cancer cells and MCF-7-LCC2 cells, a tamoxifen resistant derivative of MCF-7 [30]. ER $\alpha+$ Ishikawa endometrial adenocarcinoma cells did not exhibit substantial phosphorylation at S559, and weak immunoreactivity for S294 and S282 phosphorylation observed. These studies indicate that ER $\alpha$ is phosphorylated at serines S282, S294, and S559 in endogenous ER $\alpha$ expressing breast and endometrial cancer cells. It should be noted that phosphospecific antibodies for p-S282, pS294, and p-S559 also detected phosphorylated ER $\alpha$ in $\mathrm{ER} \alpha$ positive human breast carcinomas [13].

To determine if the phosphorylation of ER at S282, S294, or S559 was regulated by estradiol, MCF7 cells were incubated for 30 minutes with $10^{-8} \mathrm{M}$ estradiol. Estradiol markedly increased phosphorylation at sites S282 and S559 but had little effect on S294 (Figure 6B). These data 


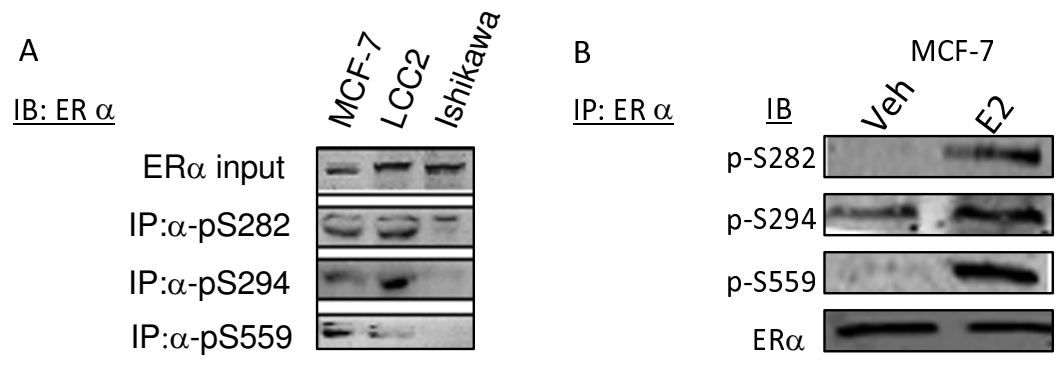

\section{Figure 5}

Phosphorylation of endogenous ER $\alpha$ in ER $\alpha$ (+) cell lines at S282, S294, and S559. (A) I07 MCF-7 and MCF-7(LCC2) breast cancer and Ishikawa endometrial adenocarcinoma cell lines were cultured in medium supplemented with $10 \%$ FBS. Cells were lysed and total ER $\alpha$ was immunoprecipitated with $\alpha$-p-S282, $\alpha$-p-S294, or $\alpha$-p-S559 antibodies for 3 hours. Immunoprecipitates were analyzed by Western blot for total ER $\alpha$ (B) S282 and S559 are phosphorylated following incubation of MCF-7 breast cancer cells with estradiol. MCF-7 breast cancer cells were cultured for 48 hours in phenol red free medium supplemented with $10 \%$ charcoal-stripped FBS. Cells were serum starved overnight prior to incubation with vehicle (veh) or 10-8M estradiol (E2). ER $\alpha$ was immunoprecipitated from lysates and Western blot analysis performed with $\alpha-p S 282, \alpha-p S 294$, or $\alpha$-pS559, and with $\alpha$-ER $\alpha$. Substantial ligand-induced phosphorylation was detected at S282 and S559, with only modest ligand induced phosphorylation at S294.

further demonstrate that phosphorylation of ER $\alpha$ at S282, S294 and S559 comprise an integral component of endogenous ER $\alpha$ signaling.

\section{$E R \alpha$ phosphorylation at novel sites impacts $E R \alpha$ regulated gene expression}

To determine the role of $\mathrm{ER} \alpha$ phosphorylation in receptor mediated transcription, ER $\alpha$ negative $[\operatorname{ER} \alpha(-)]$ HeLa cervical cancer cells were cotransfected with individual ER $\alpha$ phospho mutant expression plasmids and a reporter plasmid ( $E_{2} E_{2}$-TK-luciferase) containing two canonical ERE sequences. Mutation of a serine residue to non-phosphorylatable alanine mimics loss of a phosphorylation site. S282A and S559A exhibited a significant increase in basal reporter activity compared to wt ER $\alpha$ but these mutants exhibited no statistical difference compared to wt ER $\alpha$ in estradiol-dependent reporter activation (Figure 5A). S294A exhibited reduced estradiol-dependent reporter activation. S47A mutants showed a trend toward increased basal and ligand dependent activation in reporter assays, but did not reach statistical significance. These data suggest that phosphorylation at sites S282 and S559 inhibit ligand-independent activation of ER $\alpha$, and that phosphorylation at S294 is required for full estradiol activation of gene transcription.

Real time RT-PCR was used to measure expression of the endogenous estrogen responsive gene pS2 in HeLa cells transiently transfected with wt ER $\alpha$ or mutant ER $\alpha$ expression plasmids. The pS2 promoter contains separate ERE and AP-1 sites [31,32]. Most intriguing and consistent with the reporter gene results in Figure 5A, expression of S559A resulted in significantly elevated ligand independent activation of pS2 (Figure 5B). Similarly, S282A also resulted in elevated ligand independent activation of pS2. S47A exhibited significant repression of estradiol-induced pS2 expression, which was in contrast to what was observed with the reporter gene assay. S294A exhibited no change in either basal or estradiol induced pS2 expression compared to wt ER $\alpha$. The differential effects observed with regard to S47A and S294A regulation of pS2 versus the $\mathrm{ERE}_{2}$-TK-luciferase reporter gene likely reflect gene specific effects for ER $\alpha$ phosphorylation. Interestingly, the ERE of the $\mathrm{pS} 2$ gene works in synergy with an adjacent AP-1 site to mediate estradiol induced pS2 expression [31,33]. Figure $5 \mathrm{C}$ demonstrates that an equivalent level of ER $\alpha$ protein was detected for wt ER $\alpha$ and the mutants.

One limitation of ER $\alpha(-)$ cells such as HeLa to study pS2 or other endogenous gene expression, is that these cells do not express pS2 and cells transiently transfected with ER $\alpha$ expression plasmids likely produce low levels of pS2 protein following estradiol treatment due to limitations of the transient transfection approach. Future studies will directly mutate ER $\alpha$ phosphorylation sites of the endogenous ESR-1 gene in cells that robustly express ER $\alpha$ to overcome the limitations of transient transfection employed here.

Although biochemical identification and site directed mutagenesis identified S47 as a novel phosphorylation site in phosphopeptide D, the $\alpha$-pS47 phosphospecific antibody retained immunoreactivity with $\mathrm{S} 47 \mathrm{~A}$. Since $\lambda$ phosphatase resulted in loss of immunoreactivity of $\alpha$ pS47 antibody the possibility was raised that the adjacent serine, S46, might be phosphorylated in the S47A mutant. NetPhosK software revealed that $\mathrm{S} 46$ forms a putative recognition sequence for protein kinase $\mathrm{C}$ classic isoforms 
A

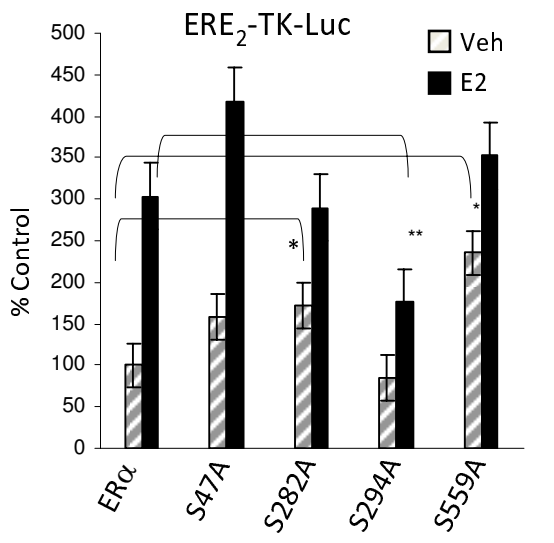

C

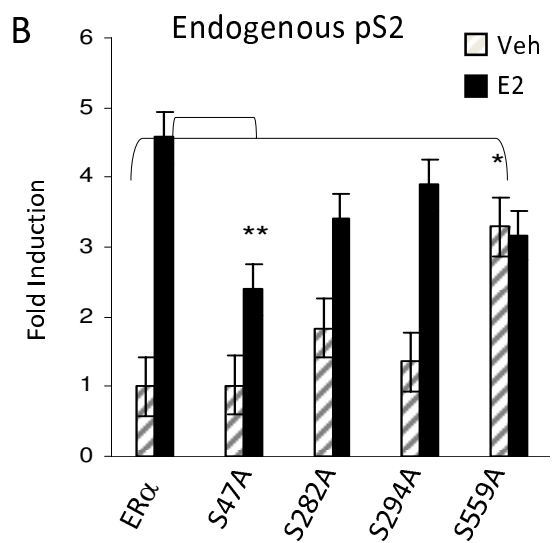

E2

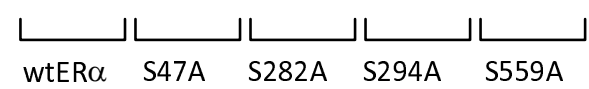

\section{Figure 6}

Phosphorylation of ER $\alpha$ impacts receptor transcriptional activity. (A) ER $\alpha$ (-) HeLa cells were cotransfected with $100 \mathrm{ng} \mathrm{ERE}_{2}$-TK-luciferase reporter and $200 \mathrm{ng}$ wt ER $\alpha(\mathrm{wt})$, or serine to alanine mutants of ER $\alpha$ for each novel phosphorylation site (S47A, S282A, S294A, and S559A). 24 hours post transfection, cells were incubated with vehicle (veh) or estradiol (I0$8 \mathrm{M}$ ) overnight. Luciferase assays were performed and transcriptional activity was normalized to protein concentration and/or ER $\alpha$ expression by Western blot analysis. S47A exhibited similar transcriptional activity to wt ER $\alpha$, whereas S294A resulted in suppressed transcriptional activity vehicle and estradiol. S282A and S559A displayed enhanced ligand independent transcriptional activity as compared to wt ER $\alpha$. (B) HeLa cervical cancer cells were transfected with $500 \mathrm{ng}$ of wt ER $\alpha$ or ER $\alpha$ phospho-mutant (S47A, S282A, S294A, S559A) expression plasmids. 24 hours post-transfection, cells were incubated with vehicle (veh), $10^{-8}$ estradiol (E2), for 3 hours. pS2 expression was measured by real-time RT-PCR, relative to GAPDH. S47A resulted in suppression of estradiol-induced pS2 expression, whereas S559A exhibited ligand-independent activation of ER. S282A and S294A displayed no statistical differences in pS2 mRNA. (C) HeLa cells were transfected with 500 ng of wt ER $\alpha$ or ER $\alpha$ phospho-mutant (S47A, S282A, S294A, and S559A) expression plasmids and incubated for 3 hours with estradiol (I-8M) at I8-24 hours post transfection. Transfection and incubation with estradiol were performed in parallel with those for RT-PCR (panel B). A and B represent composite results for 6 identical experiments. Statistical significance was determined using ANOVA and Fisher's LSD post-hoc analysis, $\mathrm{p} \leq 0.05$.

that more closely resembles a canonical recognition motif for PKC classical isoforms than does S47. To investigate the possibility that $S 46$ phosphorylation could be an alternative phosphorylation site for $\mathrm{S} 47$ of $\mathrm{ER} \alpha$, serine to alanine mutations were introduced at S46 and/or S47 (S46A, S46/S47A). ER $\alpha(-)$ HeLa cervical cancer cells were cotransfected with S46A, S47A, or S46/47A expression plasmids and $\mathrm{ERE}_{2}$-TK-luciferase reporter plasmid. Results indicated that mutation of S46, but not S47, significantly suppressed ER $\alpha$ transcriptional function (Figure 7A). The 46/47A mutant displayed similar activity to S46A, suggesting that the predominant effect on transcriptional activity was through S46 phosphorylation.

\section{Protein kinase CK2 phosphorylates ER $\alpha$ S282 and S559 in vitro and in vivo}

Motif analysis revealed that each phosphorylation site was contained within known kinase recognition motifs (Table
2). $\$ 46 / 47$ was present within an imperfect recognition motif for classical PKC isoforms (S/T-X-K/R). S282 and S559 were present within a consensus sequence for protein kinase CK2 phosphorylation (S/T-X-X-E). S294 was present within a putative recognition motif for Ser/Pro directed kinases. In vitro phosphorylation of baculovirus expressed human ER $\alpha$ was performed with ERK1/2 (to assess S294 phosphorylation), and protein kinase CK2 $\alpha$ catalytic subunit (to assess S282 and S559 phosphorylation) followed by Western blotting with phospho-specific antibodies. In vitro kinase assays with ERK1/2 did not result in phosphorylation at S294 (data not shown). Incubation of ER $\alpha$ with protein kinase CK2 resulted in phosphorylation of S282 and S559 in vitro (Figure 8A). These findings are of significant interest with regard to CK2 overexpression documented in various cancers, including breast cancer [34]. 
To demonstrate the involvement of CK2 in the phosphorylation of ER $\alpha$ at S282 and S559 in vivo, MCF7 cells were incubated with the highly selective CK2 inhibitor, DMAT (2-dimethylamino-4,5,6,7- tetrabromo-1H-benzimidazole) for 1 hour, prior to incubation with E2 for 30 minutes. Cell lysates were subjected to immunoprecipitation with $\alpha$-pS282 and $\alpha$-pS559 antibodies, and subsequently Western blots using antibody to total ER $\alpha$ protein. DMAT suppressed phosphorylation of S282 and S559 further indicating that CK2 is responsible for the phosphorylation of both S282 and S559 of ER $\alpha$ (Figure 8B).

\section{Discussion}

The present study has characterized four novel phosphorylation sites in human ER $\alpha$ in vivo. Two of these sites, S294 and S559, have been independently confirmed by mass spectrophotometry in MCF-7 cells [11]. Additionally, collaborators at the University of Manitoba recently found that ER $\alpha$ is phosphorylated at S282, S294, and S559 in human breast carcinoma biopsies, lending evidence to the physiological relevance of these sites in the breast cancer [13]. S559 phosphorylation is the first phosphorylation site identified in the extreme C-terminal (F domain) of a steroid nuclear receptor [35]. Generation of phospho-specific ER $\alpha$ antibodies provided the tools to validate phosphorylation sites and to begin to assess the functional significance of these specific sites. Accordingly, these phospho-specific antibodies were used to detect phosphorylation of each residue by Western blot/immunoprecipitation from cells that expressed endogenous ER $\alpha$ (Figure 6A and 6B). Phosphorylation at S46/47, S282, S294 and S559 each had an impact on ER $\alpha$ mediated activation of reporter gene $\mathrm{ERE}_{2}$-TK-luciferase and/or endogenous pS2 gene expression (Figure 5A and 5B). Two of these sites, S282 and S559, were contained within consensus sequences for protein kinase CK2 and were phosphorylated by CK2 in vitro and in vivo (Figure 7,8 ). In particular, phosphorylation changes at the F domain S559 site had profound effects on ligand independent activation of $\mathrm{ER} \alpha$. These findings provide valuable insight into the regulation of ligand dependent and ligand independent ER $\alpha$ function. Furthermore, pharmacological targeting of the cell signaling pathways that regulate ER $\alpha$ phosphorylation at these sites may represent therapeutic targets for modulating ER $\alpha$ function.

S559, located in the F-domain of ER $\alpha$, represents a very intriguing phosphorylation site because mutation to alanine enhances ligand independent activation of ER $\alpha$ (Figure 5A and 5B). Studies have demonstrated that the Fdomain of various nuclear receptors may be responsible for interaction with coregulators, and for determining the relative agonist/antagonist character of several ER $\alpha$ ligands [36]. At least two groups have demonstrated that Fdomain deletions, that included deletion of a regions con- taining S559, enhanced transcriptional activity of ER $\alpha$ $[37,38]$. Furthermore, SRC-1 association with ER $\alpha$ was increased upon deletion of the F domain [39]. Another report demonstrated that the intact ER $\alpha$ F-domain inhibited the association of unliganded ER with REA (Repressor of Estrogen Receptor) using in vitro GST pull down assays [40]. These studies indicate that the F-domain of ER $\alpha$ was responsible for the inhibition of ER $\alpha$ association with both coactivators (SRC-1) and corepressors (REA). Although these findings do not directly implicate a central role for S559 phosphorylation in coregulator recruitment, it does highlight the importance of the F-domain in ER $\alpha$ / coregulator interactions. Interestingly, another report suggested that point mutations of S559 and E562 to alanine disrupted a predicted helix in the F-domain that resulted in a slight inhibition of ligand independent transcriptional activity and an enhanced estradiol-activation of $\mathrm{ER} \alpha$ mediated gene expression [38].

The phosphorylation of S282 and S294 may also be important for regulating ER $\alpha$ function. The location of S282 and S294 in the hinge region near the DBD is suggestive of a role for these phosphorylation sites in DNA binding and/or dimerization of ER $\alpha$. The present data, however suggest that phosphorylation of these residues lead to opposing effects on ER $\alpha$ mediated transcription (Figure 5A and 5B). Reporter gene data suggest that phosphorylation at S282, much like S559, was involved in the suppression of unliganded ER $\alpha$ activity. However, mutation of S282 also resulted in increased estradiol-dependent loss of ER protein. As such, the impact of S282 phosphorylation may be biphasic. In the transient setting, S282 phosphorylation may result in attenuated transcriptional activity but may lend to long term stabilization of ER protein levels allowing transcriptional activity to persist over time. S294 mutation to alanine resulted in a suppressive effect in reporter assays but not in expression of the endogenous estrogen regulated gene pS2. One likely explanation is that the complexity of the endogenous pS2 promoter allows other transcription factors/transcriptional regulators to compensate for loss of ER $\alpha$ function caused by mutation of S294 to alanine. The pS2 promoter does indeed contain an AP-1 site that is thought to act in concert with the ERE to mediate transcriptional activity. In this setting, slight changes in ERE mediated transcriptional function may be compensated with the AP-1 site.

S46/47 phosphorylation may play a role in the ligand dependent activation of ER $\alpha$. Data suggested that S46, and not S47, is responsible for regulating ER $\alpha$ transcriptional activity. $\$ 47$ which was identified by biochemical means, may be phosphorylated due to a "bystander effect" in which kinases, (presumably PKC isoforms) are directed to the S46 site but may phosphorylate both the S46 and the weaker recognition site, S47. Alternatively, S46 and 
A

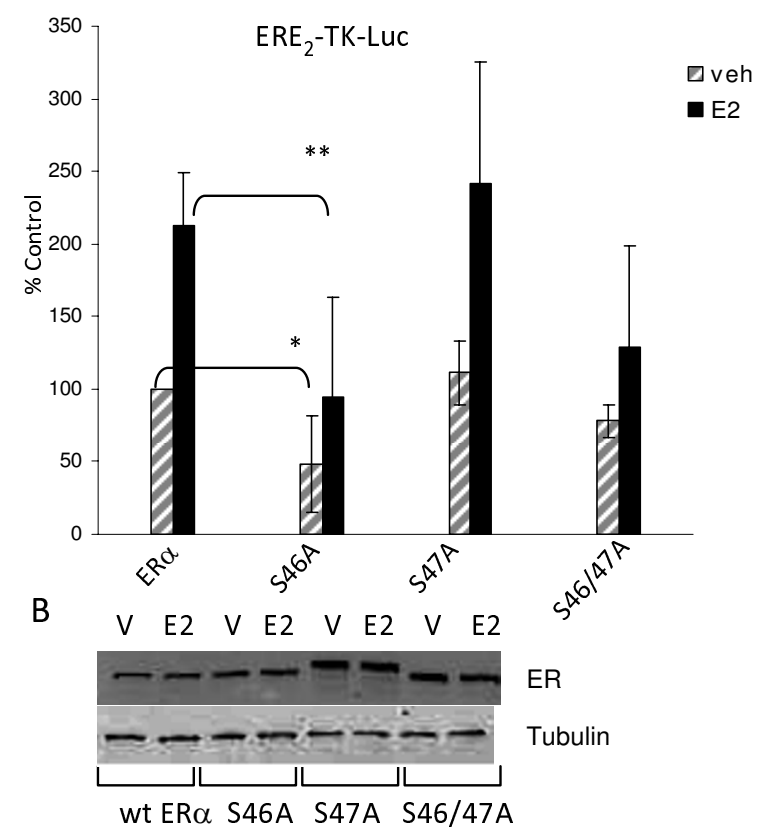

Figure 7

Mutation of S46 and S46/47 impacts receptor transcriptional activity. (A) $10^{5} \mathrm{ER} \alpha$ (-) HeLa cells were cotransfected with $100 \mathrm{ng} \mathrm{ERE}_{2}$-TK-luciferase reporter and $200 \mathrm{ng} w \mathrm{ER} \alpha(\mathrm{wt})$, or serine to alanine mutants of $E R \alpha$ for S46 (S46A), S47A (S47A), or both S46 and S47 (S46/47A). 24 hours post transfection, cells were incubated with vehicle (veh) or estradiol (10-8 M) for 18-24 hours. Luciferase assays were performed to determine the relative transcriptional activity of $E R \alpha$ and $E R \alpha$ phospho-mutants. Transcriptional activity was normalized to protein concentration and $E R \alpha$ expression by Western blot analysis. These studies demonstrate that S46A and S46/47A lead to substantial inhibition of $E R \alpha$ mediated gene expression, whereas the activity of S47A remains similar to that of wt ER $\alpha$. (B) Western blot analysis demonstrating expression of wt ER $\alpha$, S46A, S47A, and S46/ 47A. $10^{5} \mathrm{HeLa}$ cells were transfected with $500 \mathrm{ng}$ of wt ER $\alpha$ or ER $\alpha$ phospho-mutant (S46A, S47A, or S46/47A) expression plasmids and incubated for 5 hours with estradiol $(1-8 \mathrm{M})$ at 18-24 hours post transfection. S47A shows an electrophoretic upshift not evident with wt ER $\alpha$, S46A, or S46/47A. Panel A represents the composite of 3 experiments. Statistical significance was determined using ANOVA and Fisher's LSD post-hoc analysis, $\mathrm{p} \leq 0.05$.

S47 phosphorylation events could be distinct events. Indeed, S46 lies within an imperfect protein kinase $\mathrm{C}$ recognition motif as does $S 47$ and mutation of $S 46$ results in substantial inhibition of ERE-luciferase activity in HeLa cells but was not identified biochemically as an ER $\alpha$ phosphorylation site. Interestingly, mutation of S46 or S46/47 does not lead to the electrophoretic up shift observed upon mutation of S47 alone suggesting that these sites play distinct roles in ER transcriptional regulation. These data can only be suggestive of S46 phosphorylation as there has been no direct biochemical evidence that $\mathrm{S} 46$ is phosphorylated. As with the other four A/B region phosphorylation sites (S104, S106, S118, S167), S47 may contribute to the ligand independent and ligand dependent function of the receptor. In agreement with this assertion it has been demonstrated that murine ER $\alpha$ transcriptional activity is induced by PKC $\delta$ through the AF- 1 domain and that PKC $\delta$ activity leads to phosphorylation of mouse ER $\alpha$ [41]. Nonspecificity of the $\alpha$-pS47 antibody precluded further experiments that would have been necessary to determine if PKC is indeed necessary for the phosphorylation of $S 46 / 47$ and if this mediates the transcriptional induction of ER $\alpha$ through the PKC pathway.

The finding that S282 and S559 were phosphorylated in vivo and in vitro by protein kinase CK2 indicates a central role for CK2 in the regulation of ER $\alpha$ transcriptional activity (Figure 7). Previous studies indicate that CK2 enhances ER $\alpha$ DNA binding in vitro and that CK2 phosphorylates $\mathrm{ER} \alpha$ at serine $167[9,10,42]$. Previous work from this laboratory demonstrated that mutation of S167 to alanine markedly reduced ER $\alpha$ transcriptional activity and disrupted ER $\alpha$ interaction with endogenous promoters [4]. S282 and S559 represent the second and third sites of ER $\alpha$ regulation by CK2. Remarkably, mutation of S282 or S559 to alanine resulted in near opposite functional effects on ER $\alpha$ as compared to mutation of S167 to alanine. ER $\alpha$ ligand independent transcriptional activity was markedly enhanced upon mutation of S282 and S559 to alanine whereas estradiol mediated activation remained equivalent to wt $\mathrm{ER} \alpha$ (Figure $5 \mathrm{~A}$ and $5 \mathrm{~B}$ ). These findings suggested that CK2 phosphorylation maintains $E R \alpha$ in a state in which basal ligand independent activity is suppressed while responsiveness to ligand is retained. This is significant in that CK2 overexpression has been observed in several cancers including breast cancer $[34,43]$. It has also recently been demonstrated that several tamoxifen resistant breast cancer cell lines showed greater susceptibility to apoptosis upon inhibition of CK2 compared to tamoxifen sensitive MCF-7 cells [44]. Additionally, developmental mouse models reveal a causative role for CK2 in breast cancer in which MMTV-CK2 $\alpha$ transgenic mice form mammary tumors at a frequency of $35 \%$ as compared to $>1 \%$ in wt FVB mice [43]. Therefore, the signaling axis of ER $\alpha$ and CK2 in breast cancer is of great interest and provides a putative target for therapeutic intervention.

The signaling axis between CK2 activity and ER $\alpha$ transcriptional regulation has yet to be elucidated. Though mutagenesis of sites demonstrated that absence of a phosphorylation event at S282 and S559 positively regulated 
ER transcriptional activity, inhibition of CK2 by DMAT inhibited ER transcriptional activity (data not shown). One possibility to explain these findings is that CK2 may be necessary for the activity of transcriptional coregulators involved in ER signaling. A second explanation may be that ER is phosphorylated by CK2 at additional sites (e.g. S167).

Sequence alignment analysis $\left(\right.$ Megalign $^{\mathrm{TM}}$, DNA*Star) was used to determine conservation of phosphorylation at S47, S282, S294, and S559 among other nuclear receptors. S47, which lies in the highly heterologous and heavily phosphorylated AF-1 region of $\mathrm{ER} \alpha$, was difficult to align with AF-1 regions of other nuclear receptors and consequently it was difficult to assess conservation of this site among receptors. However because there is more homology within the DBD, hinge and LBD regions of nuclear receptors, phosphorylation at sites equivalent to S282, S294 and S559 may be more highly conserved among nuclear receptors. The hAR (human androgen receptor) is phosphorylated by stress kinases (ie. Jun $\mathrm{N}$ terminal Kinase, p38 MAP kinase) within the hAR hinge region (S650), a site that is homologous to and aligns
A

In Vitro

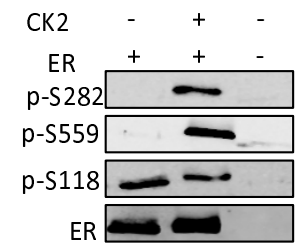

B

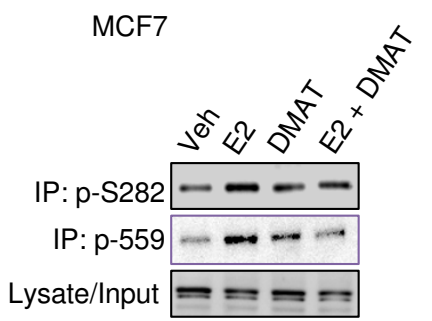

\section{Figure 8}

Protein Kinase CK2 phosphorylates of S282 and

S559. (A) $400 \mathrm{ng}$ baculovirus expressed ER $\alpha$ was incubated in CK2 kinase buffer supplemented with $10 \mathrm{mM}$ ATP, in the presence or absence of $200 \mathrm{ng}$ recombinant catalytic $\alpha$ subunit of CK2. Reactions were stopped with Laemmli buffer, subjected to Western blot analysis, and probed with $\alpha$ pS282, $\alpha$-pS559, $\alpha$-pSI I 8 or $\alpha$ ER. These studies show that the CK2 $\alpha$ catalytic subunit specifically phosphorylates $E R \alpha$ at S282 and S559. Western blot for phosphorylation of SI I8, a site that exhibits strong phosphorylation in baculovirus expressed $E R \alpha$, is shown for comparison to demonstrate absence of nonspecific phosphorylation by CK2 on other ER $\alpha$ phosphorylation sites. (B) $10^{6}$ MCF7 breast cancer cells were pretreated with DMAT (4 uM) for 90 minutes, followed by 30 minutes with estradiol $\left(10^{-8} \mathrm{M}\right)$ or vehicle. Immunoprecipitation of S282 or S559 was performed using phosphoantibodies and Western blot for total ER $\alpha$. DMAT inhibited phosphorylation at both sites, indicating that CK2 phosphorylates these sites in vivo. closely with S282 of ER $\alpha$ [45]. Interestingly, the (S)PTEE sequence encompassing S650 comprises a putative CK2 recognition motif as does S282, suggesting some conservation in phosphorylation between ER $\alpha$ and hAR. Functionally, S650 phosphorylation of the hAR is suggested to regulate nuclear export [46]. The hPR-B (human progesterone receptor $\mathrm{B}$ ) is phosphorylated in the hinge region by CDK2 at S676 [47]. However S676 phosphorylation has not been ascribed mechanistic relevance in hPR-B function and this site does not align closely with ER $\alpha$ S282 or hAR S650 in alignment analysis. It is possible however, that phosphorylation of hPR-B at $\mathrm{S} 676$ is homologous to ER $\alpha$ S294. S294 is likely targeted by Serine-Proline (Ser-Pro) directed kinases and is located within the hinge domain of ER $\alpha$. Regarding S559 phosphorylation, to date no phosphorylation site has been identified in the F domain of steroid receptors [35].

Motif analysis identified kinase recognition sequences in other nuclear receptors that may be analogous to CK2 phosphorylation of S282 and S559. ER $\beta$ has putative CK2 recognition sites at S234 (SADE) and S513 (SPAE). S225 of RXR $\alpha$ (retinoid $\times$ receptor alpha) is contained within a putative CK2 site (SANE) that aligns with, and may be homologous to, S282 of ER $\alpha$. The relatively high number of putative CK2 phosphorylation sites within nuclear receptors may indicate that $\mathrm{CK} 2$ phosphorylation is intrinsically linked to cell cycle progression given that CK2 expression and activity is increased in highly proliferating tissues [48].

These studies represent the first characterization of four newly identified phosphorylation sites within ER $\alpha$. One caveat to these findings is the use of $\mathrm{ER} \alpha(-)$ HeLa cells to determine the impact of each phosphorylation site on ER $\alpha$ transcriptional activity. HeLa cells only weakly support AF-1 activity of ER $\alpha$. As such, these studies may represent mechanisms that are primarily representative of AF2 regulation. Indeed, three of the four identified phosphorylation sites lie outside of the AF1 domain suggesting that these sites may function independently of AF-1. However this does not preclude phosphorylation dependent interaction between AF-1 and AF-2 domains. Despite these limitations, Hela cells support ER $\alpha$ transcriptional activity in luciferase reporters and demonstrate the regulation of endogenous estradiol regulated genes. Additionally, because the cells are ER $\alpha(-)$, the influence of endogenous ER $\alpha$ expression on estradiol-mediated gene transcription is not present.

\section{Conclusion}

The study presented herein describes the initial identification and/or functional characterization of S46/47, S282, S294, and S559 as phosphorylation sites within ER $\alpha$. These studies show that phosphorylation at $\$ 46 / 47$ or at 
S294 likely potentiate ER $\alpha$ transcriptional activity whereas S282 and S559 phosphorylation are likely to negatively regulate $\mathrm{ER} \alpha$ transcriptional activity as evidence by mutational analysis. Additionally, this study identified protein kinase CK2 as the kinase responsible for the phosphorylation of ER $\alpha$ at S282 and S559. The identification and characterization of phosphorylation at S46/47, S282, S294, and S559 provides additional insight into regulation of ER $\alpha$ signaling. Ultimately, the impact of ER $\alpha$ phosphorylation at these sites will provide new diagnostic tools in breast cancer and may lead to novel therapeutic strategies to target $\mathrm{ER} \alpha$ signaling.

\section{Methods}

\section{Tissue culture and transfection}

COS-1 monkey embryonic kidney cells, HeLa human cervical cancer cells, MCF-7 cells (ATCC, Manassas, VA), and MCF-7-LCC2 (from Robert Clarke, Ph.D., Georgetown Univ.) were cultured in Dulbecco's minimum essential medium (DMEM) supplemented with 10\% fetal bovine serum (FBS), and $5 \%$ penicillin/streptomycin at $37^{\circ} \mathrm{C}$ and $5 \% \mathrm{CO}_{2}$. Ishikawa cells (provided by Steven Safe, Ph.D., College Station, TX) were cultured at $37^{\circ} \mathrm{C}$ with $5 \% \mathrm{CO}_{2}$ in DMEM supplemented with 5\% FBS and 1\% penicillinstreptomycin. Prior to incubation with estradiol $\left(10^{-8} \mathrm{M}\right)$ or tamoxifen $\left(10^{-7} \mathrm{M}\right)$, cells were cultured in phenol redfree DMEM or RPMI 1640 supplemented with 10\% charcoal dextran stripped FBS, and 5\% penicillin/streptomycin for a minimum of 24 hours. Transient transfections were performed using Fugene 6 and in accordance with the manufacturer instructions. To attain higher transfection efficiency, modified inactive (dead) adenovirus was used as a transfection reagent for the in vivo labeling experiments as previously described [26]. Briefly, 500 ng plasmid DNA and attenuated adenovirus (multiplicity of infection, 400) were diluted in HEPES buffered saline, to which poly-L-lysine was added to a final concentration of $12.5 \mathrm{ng} / \mathrm{ml}$. Adenovirus/lysine solution was applied to COS- 1 cells $\left(2 \times 10^{6}\right)$ plated in serum free media. Two hours post-transfection, DMEM containing $10 \%$ charcoal stripped FBS was added to cells.

\section{In vivo labeling and isolation of $E R \alpha$}

This laboratory previously described a detailed procedure for in vivo $\left.{ }^{32} \mathrm{P}\right] \mathrm{H}_{3} \mathrm{PO}_{4}$ labeling of nuclear receptors and coactivators in mammalian cells $[26,28,49]$. Briefly, COS1 cells were cultured in $150 \mathrm{~mm}$ tissue culture plates $(4 \times$ $10^{7}$ cells/plate) in DMEM supplemented with charcoal dextran stripped FBS. Medium was replaced with serumfree medium and cells were transfected using an adenovirus mediated transfection protocol (see Tissue Culture). Prior to in vivo phosphate labeling, transfected cells were incubated for 1.5 hours in serum free, phosphate-free DMEM with $1 \%$ penicillin/streptomycin to deplete intracellular phosphate pools. Subsequently medium was replaced with DMEM supplemented with $1 \%$ dialyzed FBS (to remove low molecular weight molecules such as phosphates). Immediately after medium exchange, 4 $\mathrm{mCi} /$ plate of $\left.{ }^{32} \mathrm{P}\right] \mathrm{H}_{3} \mathrm{PO}_{4}$ along with estradiol (final concentration of $10^{-8} \mathrm{M}$ ) was added to each plate and cells were incubated at $37^{\circ} \mathrm{C}$ and $5 \% \mathrm{CO}_{2}$ for approximately 16 hours overnight. Following removal of medium and several washes with PBS, cells were harvested by scraping, cells were pelleted by centrifugation $(500 \times \mathrm{g})$, and protein was extracted using 4 pellet volumes (approximately $2 \mathrm{mls})$ of denaturing lysis buffer $(10 \mathrm{mM}$ Tris $\mathrm{pH} 8,50$ $\mathrm{mM}$ potassium phosphate, $50 \mathrm{mM}$ sodium fluoride, 1 $\mathrm{mM}$ sodium vanadate, $2 \mathrm{mM}$ EDTA, $2 \mathrm{mM}$ EGTA, $0.4 \mathrm{M}$ sodium chloride, $5 \mathrm{mM} \alpha$-monothioglycerol, $8 \mathrm{M}$ urea, and $1 \times$ Pierce HALT protease inhibitor cocktail). Chromatin/DNA in the lysate was sheared by $8-10$ passes through a 25 gauge needle and syringe. DNA and cellular debris was removed by ultracentrifugation at $100,000 \mathrm{~g}$ for 20 minutes at $4^{\circ} \mathrm{C} .100 \mu \mathrm{l}$ of cleared lysate was retained for Western blot analysis while the remaining 2 $\mathrm{ml}$ of cleared lysate was diluted 1:20 in PBS/0.1\%BSA to dilute the urea and prepare the lysate (total volume 40 $\mathrm{ml}$ ) for immuno-affinity columns. ER $\alpha$ was purified using an immuno-affinity column consisting of protein A conjugated sepharose beads $(500 \mathrm{ml})$ bound by $0.5 \mathrm{mg}$ mouse monoclonal anti ER $\alpha$ Ab (D12, Santa Cruz). Lysates were passed over columns two times using a peristaltic pump over a period of approximately 2-3 hours. Columns were washed using $300 \mathrm{ml}$ PBS/0.1\%BSA/.01\% TWEEN 20 over a period of approximately 1 hour. Sepharose beads were collected in PBS, ER $\alpha$ was eluted in $2 \times$ Laemmli buffer and the samples were electrophoresed on a $10 \%$ SDS PAGE gel. Following autoradiography of the wet gel and comparison to Western blot for ER $\alpha$, the corresponding ER $\alpha$ band was excised from the wet gel in preparation for trypsin digestion (see below).

\section{Phosphopeptide mapping}

Phosphopeptide mapping of nuclear receptors and coregulators has been previously described $[26,28,28,50,51]$. Briefly, gel slices corresponding to ER $\alpha$ or ER $\alpha$ phosphomutants were excised from wet gels and incubated for 30 minutes in $50 \%$ methanol/HPLC $\mathrm{H}_{2} \mathrm{O}$ followed by brief washes in HPLC-grade water to remove SDS and electrophoretic salts from the sample. Gel slices were then digested with $10 \mu \mathrm{g}$ trypsin in $50 \mathrm{mM}$ ammonium bicarbonate buffer for 4 hours. $10 \mu \mathrm{g}$ of additional trypsin was added in 3 hour intervals for a total addition of $40 \mu \mathrm{g}$ trypsin. Samples were lyophilized overnight in a SpeedVac, and the samples were resuspended in $500 \mu \mathrm{l} 50 \%$ formic acid solution in preparation for HPLC separation. The sample containing tryptic ER $\alpha$ peptides was loaded onto a C-18 reversed phase column (Vydac) using a Beckman Coulter System Gold ${ }^{\circledast}$ HPLC. A $0-45 \%$ acetonitrile gradient over 90 minutes was used to elute phosphopeptides 
from the column. Each HPLC fraction was lyophilized, and Cerenkov counts were measured. Based on Cerenkov counts related to ${ }^{32} \mathrm{P}$ peaks, HPLC fractions were combined in alkaline polyacrylamide gel sample buffer $(0.125$ $\mathrm{M}$ Tris, pH 6.8, $6 \mathrm{M}$ urea, $0.01 \%$ bromphenol blue prepared fresh) to yield 10-13 sample groups. Individual phosphorylated tryptic peptides were separated on $40 \%$ alkaline polyacrylamide gels [26]. The gel was dried and autoradiographed for 2-10 days.

\section{Modified manual Edman degradation}

A modified version of manual Edman degradation was performed on phosphopeptides using the Millipore (Billerica, MA) Sequelon-AA acrylamine disks as previously described by this laboratory [28]47). Briefly, manual Edman degradation was performed on phosphopeptides isolated from either alkaline polyacrylamide gel slices or directly from HPLC fractions. Phosphopeptides gel slices from alkaline polyacrylamide gels were washed in 50\% methanol and the peptides extracted overnight in HPLC water. The extracted peptides were lyophilized, Cerenkov counts measured, and the phosphopeptides were resuspended in $30 \mu \mathrm{l} 50 \%$ acetonitrile/0.1 TFA. For HPLC fractions, the lyophilized fractions were directly resuspended in $30 \mu \mathrm{l} 50 \%$ acetonitrile/0.1 TFA.

A mylar membrane was placed on a $55^{\circ} \mathrm{C}$ dry bath and peptides were spotted on Sequelon-AA disks and disks were dried for $15 \mathrm{~min}$. Peptides were coupled to membranes by adding $5 \mu \mathrm{l}$ carbimide $(10 \mathrm{mg} / \mathrm{ml})$ for $30 \mathrm{~min}$ utes at room temperature. Membranes were sequentially washed in HPLC $\mathrm{H}_{2} \mathrm{O}, 100 \%$ TFA, and $100 \%$ methanol. Phenylisothiocyanate was coupled to the N-terminus of immobilized phosphopeptides to sensitize the peptides to N-terminal cleavage. Disks were washed in methanol, dried by SpeedVac, and incubated in $0.5 \mathrm{ml}$ TFA for $6 \mathrm{~min}$ at $55^{\circ} \mathrm{C}$. The TFA solution was collected and the disks washed with $1 \mathrm{ml} 42.5 \%$ TFA. The fractions were combined and Cerenkov counts determined as a measure of release of the phosphoamino acid residues within the peptide.

\section{Phosphoamino acid analysis}

Phosphoamino acid analysis has been described in detail previously by this laboratory $[28,51]$. Isolation of phosphopeptides by HPLC and $40 \%$ alkaline acrylamide gels is described above. Lyophilized phosphopeptides were resuspended in 100-200 $\mu \mathrm{l}$ of $6 \mathrm{~N} \mathrm{HCl}$ to which $4 \mu \mathrm{g}$ each of purified phospho-serine, phospho-tyrosine, or phospho-threonine was added. Samples were incubated 1 hour at $110^{\circ} \mathrm{C}$. Samples were dried by SpeedVac overnight, resuspended in $15 \mu \mathrm{l}$ of $\mathrm{pH} 1.9$ buffer ( $2.5 \%$ formic acid, $1.8 \%$ glacial acetic acid), and spotted on $20 \times 20 \mathrm{~cm}$ cellulose thin layer chromatography plates. Samples were electrophoresed in the first dimension for $20 \mathrm{~min}$ at 1500 V (toward negatively charged electrode) using the Hunter
HTLE 7000 electrophoresis system (CBS Scientific Del Mar, CA). After drying, plates were then subjected to second dimension electrophoresis. Plates were equilibrated in pH 3.5 buffer ( $5 \%$ glacial acetic acid, $0.5 \%$ pyridine in $\mathrm{dH}_{2} \mathrm{O}$ ) and a second round of electrophoresis was performed in $\mathrm{pH} 3.5$ buffer for 15 minutes at $1300 \mathrm{~V}$ with plates rotated $90^{\circ}$. Plates were dried for 1 hour. Ninhydrin $(5 \mu \mathrm{g} / \mathrm{ml}$ acetone, Pierce, Rockford, IL) was applied to the plates using an atomizer (General Glassblowing, Inc.) and plates incubated at $80^{\circ} \mathrm{C}$ for $1-5$ minutes to visualize phosphoamino acid standards. Standards were then outlined and radiolabeled sample phosphopeptides visualized by autoradiography. Comparison to migration of phosphoamino acid standards was used to determine the identity of phosphorylated amino acid residues.

\section{Generation of ER $\alpha$ phospho-mutants}

ER $\alpha$ S46A, S47A S46/S47A, S282A, S294A, and S559A phospho-mutant expression plasmids were constructed using the either the Quick-change $\mathrm{XL}^{\mathrm{TM}}$ (Stratagene) or GeneEditor $^{\mathrm{TM}}$ (Promega) site directed mutagenesis kit in accordance with the manufacturer's instructions. Briefly, mutagenesis primers encoding serine to alanine mutations for S47, S282, S294, and S559 were designed in accordance with Stratagene primer design software, and were as follows:

\section{S46A-Fwd:5'-.GGTGTACCTGGACGCCAG- CAAGCCCGCC}

S46A-Rev:5'-.GGCGGGCTTGCTGGCGTCCAGGTACACC S46/47A-Fwd:5'-.GGTGTACCTGGACGCCGCAAAGCCCGCC

Rev:5'-.GGCGGGCTTTGCGGCGTCCAGGTACACC

S47A- Fwd: 5'-GTGTACCTGGACAGCGCAAAGCCCGCCGTGTAC-3'

Rev: 5'-GTACACGGCGGGCTTTGCGCTGTCCAGGTACAC-3'

S282- 5'-Fwd: GGGTGAAGTGGGGGCAGCTGGAGACATGAGA-3'

Rev:5'-TCTCATGTCTCCAGCTGCCCCCACTTCACCC-3'

S294-Fwd: 5'-ACCTTTGGCCAGCCCCGCTCATGAT-3'

Rev: 5'-ATCATGAGCGGGGCCGGCCAAAGGT

S559 Fwd: 5'-GGAGGGGCAGCTGCTGAGGAGACG-3'

Rev:5'-CGTCTCCTCCACAGCTGCCCCTCC-3' 
For S47A and S282A, PCR reactions were assembled using pCR3.1wt ER $\alpha$ (template DNA), $125 \mathrm{ng}$ each fwd and rev mutagenesis primers, $1 \mu$ l Stratagene dNTP mix, and $2.5 \mathrm{u}$ $P f u$ turbo DNA polymerase. PCR conditions were as follows: $95^{\circ}$ for 50 seconds, $60^{\circ} \mathrm{C}$ for 60 seconds, and $68^{\circ} \mathrm{C}$ for 5 minutes for 18 cycles followed by final extension for 10 minutes at $68^{\circ} \mathrm{C}$. Methylated template DNA strands were digested using DPN1 and the reaction transformed into XL10 gold E. coli cells. Clones were grown on $100 \mu \mathrm{g} /$ $\mathrm{ml}$ ampicillin LB agar plates and 5 selected clones were amplified in $5 \mathrm{ml}$ liquid cultures with LB/amp medium. Mini-plasmid preps were performed using alkaline lysis and the isolated plasmid DNA sequenced to determine the incorporation of the desired serine to alanine mutations.

For S294A and S559A, alkaline denatured pCR3.1wt ER $\alpha$ (template DNA) was hybridized to mutagenic (145 ng) and antibiotic resistance oligonucleotides (2.9 ng each) and in the presence of $1 \times$ annealing buffer in $20 \mu \mathrm{l}$ a reaction volume. The reactions were heated to $75^{\circ} \mathrm{C}$, for 5 minutes, and allowed to cool to $37^{\circ} \mathrm{C}$ utilizing a thermal cycler. Mutant strands were synthesized in reaction utilizing $10 \mathrm{u}$ T4 polymerase and $3 \mathrm{u}$ DNA ligase with $1 \times$ synthesis buffer in a final volume of $30 \mathrm{ul}$, and were incubate at $37^{\circ} \mathrm{C}$ for 90 minutes. Plasmid DNA was subsequently transformed into BMH 71-18 mutS E. coli, cultured in the presence of GeneEditor $^{\mathrm{TM}}$ antibiotic selection mix overnight, and plasmid minipreps performed. A second round of plasmid minipreps were performed using DH5 $\alpha$ competent E. coli prior to usage in experiments. Plasmid DNA was subsequently sequenced to confirm serine to alanine mutations.

\section{ER $\alpha$ phospho-specific antibodies}

Generation of phospho-specific ER $\alpha$ antibodies has been previously described [29]. Briefly, rabbit polyclonal antibodies to phosphorylated peptides corresponding to phosphorylated S47, S282, S294 and S559 were generated by Bethyl Laboratories (Montgomery, Texas). Immunogenic phosphopeptides were as follows:

\section{pS47 [CEVYLDS(pS)KPAVY],}

pS282, [CGRGEVG(pS)AGDMR] pS294, [CRAANLWP(pS)PLMIK] and pS559(CTSRGGA(pS)VEET).

Rabbits were injected subcutaneously with immunogen/ adjuvant mixture that was re-administered at day 14 and day 44. Animal sera were collected on days 54 and 60, and subsequently at two week intervals. Antibody titers were measured by ELISA and phospho-specific antibodies were affinity purified with the corresponding antigen. Antibody specificity was validated as previously described [29]. Briefly, $10^{6}$ COS- 1 cells were transiently transfected with $500 \mathrm{ng} \mathrm{ER} \alpha$ or ER $\alpha$ phospho-mutant expression plas- mids with Fugene 6 in accordance with the manufacturer's instructions. Specificity of ER $\alpha$ phospho-antibodies was determined by Western immunoblotting as described below. Antibodies were further validated by in vitro $\lambda$ phosphatase treatment [29]. 400 ng of purified baculovirus expressed ER $\alpha$ was incubated with $200 \mathrm{ng} \lambda$ phosphatase in $1 \times$ phosphatase buffer for 30 minutes in a total of $200 \mu \mathrm{l}$ at $30^{\circ} \mathrm{C}$. Reactions were terminated by boiling in a final concentration of $1 \times$ Laemmli buffer for $5 \mathrm{~min}$ utes. The samples were then electrophoresed and immunoblotted using phospho-specific antibodies or total ER $\alpha$ antibodies as described below.

\section{Immunoprecipitation/Western blot analysis}

Western blot analysis for estrogen receptor has been described previously [4]. Cells were cultured in phenolred free growth medium supplemented with $10 \%$ charcoal stripped FBS for 24 hours prior to incubation of cells with estradiol. Cells were incubated with vehicle or $10^{-8}$ estradiol for 30 minutes. Total protein was extracted in high salt buffer (10 mM Tris- $\mathrm{HCl}, \mathrm{pH} 8 ; 0.4 \mathrm{M} \mathrm{NaCl} ; 2$ mM EDTA; 2 mM EGTA; 50 mM potassium phosphate; 50 $\mathrm{mM}$ sodium fluoride; $10 \mathrm{mM}$-mercaptoethanol; $0.1 \%$ Triton X-100; $0.2 \%$ protease inhibitor cocktail; and $0.1 \%$ phenylmethylsulfonyl fluoride) and samples denatured with Laemmli buffer with boiling for 3 minutes. Proteins were fractionated by SDS-PAGE on $10 \%$ polyacrylamide gels and electrophoretically transferred to nitrocellulose membranes for 2 hours. Blots were blocked in 5\% BSA TBS-T (10 mM Tris, pH 8; $150 \mathrm{mM} \mathrm{NaCl;} \mathrm{0.1 \%} \mathrm{Tween-}$ $20)$, and incubated with $\alpha$-ER $\alpha$ and $\alpha$-pER $\alpha$ primary antibodies $(1: 1000)$ overnight at $4{ }^{\circ} \mathrm{C}$. Following washes in TBS-T, secondary detection was performed using LI-COR (Lincoln, NB) near-Infrared fluorescent labeled goat $\alpha$ rabbit/ $\alpha$-mouse secondary antibodies (1:10000) and membranes were read using the LI-COR Odyssey infrared imaging system (Lincoln, NB). Primary antibodies used for Western Blot analysis included $\alpha$-ER $\alpha$ (B2051, Bethyl Labs, (Montgomery, TX) or D-12, Santa Cruz Biotechnology, Santa Cruz, CA), or custom $\alpha$-phospho-ER $\alpha$ generated at Bethyl Laboratories (Montgomery, TX) (see ER $\alpha$ phospho-specific antibodies).

For immunoprecipitation experiments, $10^{7}$ Ishikawa, MCF7, or MCF-7-LCC2, cells were lysed in IP/Western buffer $(200 \mathrm{mM}$ Tris $\mathrm{pH} 8.0,250 \mathrm{mM} \mathrm{NaCl}, 0.1 \mathrm{mM}$ EDTA, $0.5 \%$ NP-40, $0.2 \%$ protease inhibitor cocktail; and $0.1 \%$ phenylmethylsulfonyl fluoride). $5 \mu \mathrm{g}$ of $\alpha$-ER $\alpha$, pS282, pS294, or pS559 antibody and $10 \mu \mathrm{l}$ protein A conjugated magnetic beads were added to $500 \mu \mathrm{l}$ (2-3 mg total protein) cell lysate, incubated with turning at $4^{\circ} \mathrm{C}$ for 3 hours. Beads were collected using magnetic tube racks, and the beads washed 3 times with IP lysis buffer. ER $\alpha$ was eluted in $2 \times$ Laemmli with boiling for 3 minutes. Western blots were performed as described above. 


\section{Luciferase reporter assay}

HeLa cervical cancer cells were plated at $1 \times 10^{5}$ cells/well in 24 well plates in phenol red free DMEM with 10\% charcoal-stripped FBS. Cells were transfected with $100 \mathrm{ng}$ $\mathrm{ERE}_{2}$-TK-Luc reporter and $200 \mathrm{ng}$ wild type $\mathrm{ER} \alpha$ (wt ER $\alpha$ ) or ER $\alpha$ mutant expression plasmids (S47A, S282A, S294A, or S559A) using Fugene 6 as described under tissue culture and transfections). After 24 hours, each set of transfectants were incubated with vehicle or estradiol $\left(10^{-8} \mathrm{M}\right)$ for 18 hours. Cells were lysed with $200 \mu \mathrm{l} 1 \times$ reporter lysis buffer. $100 \mu$ l was loaded and luciferase activity measured using Promega ${ }^{\mathrm{TM}}$ luciferase reporter assay system. ER $\alpha /$ $\mathrm{ER} \alpha$ mutant expression was determined to be equivalent per unit protein, and luciferase reporter assay normalized to total protein. Each treatment group was plated in quadruplicate and the experiment repeated a minimum of three times.

\section{Quantitative real-time RT-PCR}

Real time RT-PCR to measure pS2 and GAPDH mRNA expression was performed using the RT-PCR primers and cycling parameters described previously [4]. Briefly, HeLa cells $\left(2 \times 10^{6}\right)$ cultured in phenol red free DMEM supplemented with $10 \%$ charcoal stripped FBS in $10 \mathrm{~cm}$ dishes were transfected with $500 \mathrm{ng}$ of ER $\alpha$ or ER $\alpha$ mutant expression plasmid. 24 hours post transfection, transfectants were incubated with vehicle or estradiol $\left(10^{-8} \mathrm{M}\right)$ for 3 hours. RNA was isolated using Trizol $^{\mathrm{TM}}$ reagent according to manufacturer protocol. Single step RT-PCR was performed using iScript ${ }^{\mathrm{TM}}$ one step RT-PCR kit, BioRad ${ }^{\mathrm{TM}}$ with 500 ng RNA in $25 \mu \mathrm{l}$ reactions. pS2 expression was normalized to GAPDH expression and expression estimated using the comparative CT method outlined in the GeneAmp 5700 users manual and as previously described by this laboratory (7). Experiments were repeated a minimum of three times.

\section{Statistical Analysis}

In RT-PCR and reporter gene expression experiments, significance differences $(\mathrm{P} \leq 0.05)$ were determined using analysis of variance (ANOVA) and Fisher's LSD post hoc analysis.

\section{In vitro kinase assay}

In vitro kinase assays were performed as previously described [29,42,43,49,52,53]. Briefly, purified baculovirus expressed ER $\alpha$ (300 ng), (Invitrogen, Carlsbad, CA) was incubated with $100 \mathrm{ng}$ recombinant human protein kinase CK2 $\alpha$ (New England Biolabs ${ }^{\mathrm{TM}}$ Ipswich, MA) isolated from E. coli in CK2 reaction buffer $(20 \mathrm{mM}$ Tris- $\mathrm{HCl}$ $50 \mathrm{mM} \mathrm{KCl} 10 \mathrm{mM} \mathrm{MgCl}_{2} \mathrm{pH}$ 7.5) supplemented with $200 \mu \mathrm{M}$ ATP for 30 minutes at $25^{\circ} \mathrm{C}$. Control reactions excluding ER $\alpha$ or CK $2 \alpha$ were also assembled to assess the specificity of experimental reactions. Reactions were stopped by addition of $2 \times$ Laemmli buffer and phosphor- ylation was determined by Western blot analysis for total $\mathrm{ER} \alpha$ and pS282 or pS559 antibodies as described above. In order to assess specificity of phosphorylation, Western blot analysis for the non-CK2 ER $\alpha$ phosphorylation site S118 was performed as described above. Experiments were performed a minimum of three times.

\section{Ethical Approval}

All research performed in this study met ethical standards approved by the Tulane Office of University Research Compliance.

\section{Authors' contributions}

CCW participated in peptide mapping experiments, mutagenesis, gene expression assays, antibody characterization, kinase activity assays, and drafted manuscript. AB participated in peptide mapping experiments, and sitedirected mutagenesis of phosphorylation sites. AEG participated in peptide mapping experiments. LMC performed immunoprecipitation and immuno-assays. CLS participated in experimental design, and mutagenesis. BGR conceptualized the study, participated in the experimental design and data interpretation, and participated in drafting the manuscript. All authors have read and approved the final manuscript.

\section{Acknowledgements}

This work was supported in part by NIH/NIDDK Grant ROIDK06832 and Department of Defense Breast Cancer Research Program Idea Award (DAMD I7-02-I-053I) and Career Development Award (DAMDI7-02-I0530) (to B.G.R), and by NIH/NCI Grant KOICAI 29078 and UNCF/Merck Postdoctoral Science Research Fellowship (to C.C.W.).

\section{References}

I. Leo C, Chen JD: The SRC family of nuclear receptor coactivators. Gene 2000, 245: I-II.

2. Leo $\mathrm{C}$, Li H, Chen JD: Differential mechanisms of nuclear receptor regulation by receptor-associated coactivator 3 . J Biol Chem 2000, 275:5976-5982.

3. Dutertre M, Smith CL: Ligand-Independent Interactions of p 160/Steroid Receptor Coactivators and CREB-Binding Protein (CBP) with Estrogen Receptor-\{alpha\}: Regulation by Phosphorylation Sites in the A/B Region Depends on Other Receptor Domains. Mol Endocrinol 2003, I7:|296-|3|4.

4. Shah YM, Rowan BG: The Src kinase pathway promotes tamoxifen agonist action in Ishikawa endometrial cells through phosphorylation-dependent stabilization of estrogen receptor (alpha) promoter interaction and elevated steroid receptor coactivator I activity. Mol Endocrinol 2005, 19:732-748.

5. Bunone G, Briand PA, Miksicek RJ, Picard D: Activation of the unliganded estrogen receptor by EGF involves the MAP kinase pathway and direct phosphorylation. EMBO J 1996, 15:2174-2183.

6. Chen D, Washbrook E, Sarwar N, Bates GJ, Pace PE, Thirunuvakkarasu $V$, et al:: Phosphorylation of human estrogen receptor alpha at serine 1 I 8 by two distinct signal transduction pathways revealed by phosphorylation-specific antisera. Oncogene 2002, $21: 4921-493$ I.

7. Medunjanin S, Hermani A, De Servi B, Grisouard J, Rincke G, Mayer $D:$ Glycogen synthase kinase-3 interacts with and phosphorylates estrogen receptor-alpha and is involved in the regulation of receptor activity. J Biol Chem 2005, 38:33006-330I4. 
8. Joel PB, Smith J, Sturgill TW, Fisher TL, Blenis J, Lannigan DA PP90(RSKI) regulates estrogen receptor-mediated transcription through phosphorylation of ser-167. Mol Cell Biol 1998, 18:1978-1984.

9. Arnold SF, Obourn JD, Jaffe H, Notides AC: Phosphorylation of the human estrogen receptor by mitogen-activated protein kinase and casein kinase II: consequence on DNA binding. Journal of Steroid Biochemistry \& Molecular Biology 1995, 55:163-172.

10. Arnold SF, Obourn JD, Jaffe H, Notides AC: Serine 167 is the major estradiol-induced phosphorylation site on the human estrogen receptor. Mol Endocrinol 1994, 8: 1208-1214.

II. Atsriku C, Britton DJ, Held JM, Schilling B, Scott GK, Gibson BW, et al:: Systematic mapping of posttranslational modifications in human estrogen receptor alpha, with emphasis on novel phosphorylation sites. Mol Cell Proteomics 2008, 3:467-480.

12. Britton DJ, Scott GK, Schilling B, Atsriku C, Held JM, Gibson BW, et al.: A novel serine phosphorylation site detected in the $\mathbf{N}$-terminal domain of estrogen receptor isolated from human breast cancer cells. J Am Soc Mass Spectrom 2008, 19:729-740.

13. Skliris GP, Rowan BG, Al Dhaheri M, Williams C, Troup S, Begic S, et al:: Immunohistochemical validation of multiple phosphospecific epitopes for estrogen receptor alpha (ERalpha) in tissue microarrays of ERalpha positive human breast carcinomas. Breast Cancer Res Treat 2008, 3:443-353.

14. Clark DE, Poteet-Smith CE, Smith JA, Lannigan DA: Rsk2 allosterically activates estrogen receptor alpha by docking to the hormone-binding domain. EMBO J 200I, 20:3484-3494.

15. Bergqvist J, Elmberger G, Ohd J, Linderholm B, Bjohle J, Hellborg $H$ et al:: Activated ERKI/2 and phosphorylated oestrogen receptor alpha are associated with improved breast cancer survival in women treated with tamoxifen. Eur J Cancer 2006, 42: II04-1112

16. Murphy LC, Niu Y, Snell L, Watson P: Phospho-Serine-I I 8 Estrogen Receptor-\{alpha\} Expression Is Associated with Better Disease Outcome in Women Treated with Tamoxifen. Clin Cancer Res 2004, 10:5902-5906.

17. Murphy L, Cherlet T, Adeyinka A, Niu Y, Snell L, Watson P: Phospho-serine- 118 estrogen receptor-alpha detection in human breast tumors in vivo. Clin Cancer Res 2004, 10:1354-1359.

18. Gee JM, Robertson JF, Gutteridge E, Ellis IO, Pinder SE, Rubini M, et al.: Epidermal growth factor receptor/HER2/insulin-like growth factor receptor signalling and oestrogen receptor activity in clinical breast cancer. Endocr Relat Cancer 2005, I 2(SuppI I):S99-SI II.

19. Sarwar N, Kim JS, Jiang J, Peston D, Sinnett HD, Madden P, et al: Phosphorylation of ER\{alpha\} at serine 1 I 8 in primary breast cancer and in tamoxifen-resistant tumours is indicative of a complex role for ER \{alpha\} phosphorylation in breast cancer progression. Endocr Relat Cancer 2006, 13:85I-861.

20. Jiang J, Sarwar N, Peston D, Kulinskaya E, Shousha S, Coombes RC, et al.: Phosphorylation of estrogen receptor-alpha at Serl67 is indicative of longer disease-free and overall survival in breast cancer patients. Clin Cancer Res 2007, 13:5769-5776.

2I. Yamashita H, Nishio M, Toyama T, Sugiura H, Kondo N, Kobayashi S, et al:: Low phosphorylation of estrogen receptor alpha (ERalpha) serine II 8 and high phosphorylation of ERalpha serine 167 improve survival in ER-positive breast cancer. Endocr Relat Cancer 2008, 15:755-763.

22. Holm C, Kok M, Michalides R, Fles R, Koornstra RH, Wesseling J, et al.: Phosphorylation of the oestrogen receptor alpha at serine 305 and prediction of tamoxifen resistance in breast cancer. J Pathol 2009, 21 7:372-379.

23. Ali S, Metzger D, Bornert JM, Chambon P: Modulation of transcriptional activation by ligand-dependent phosphorylation of the human oestrogen receptor A/B region. EMBO J 1993, I 2: II53-II60.

24. Le Goff P, Montano MM, Schodin DJ, Katzenellenbogen BS: Phosphorylation of the human estrogen receptor. Identification of hormone-regulated sites and examination of their influence on transcriptional activity. I Biol Chem 1994 269:4458-4466.

25. Kato $\mathrm{S}$, Endoh $\mathrm{H}$, Masuhiro $\mathrm{Y}$, Kitamoto T, Uchiyama S, Sasaki H, et al: Activation of the estrogen receptor through phosphorylation by mitogen-activated protein kinase. Science 1995, 270: $|49|-1494$
26. Rowan BG, Weigel NL, O'Malley BW: Phosphorylation of steroid receptor coactivator-I. Identification of the phosphorylation sites and phosphorylation through the mitogen-activated protein kinase pathway. I Biol Chem 2000, 275:4475-4483.

27. Blom N, Sicheritz-Ponten T, Gupta R, Gammeltoft S, Brunak S: Prediction of post-translational glycosylation and phosphorylation of proteins from the amino acid sequence. Proteomics 2004, 4: 1633-1649.

28. Rowan BG, Narayanan R, Weigel NL: Analysis of receptor phosphorylation. Methods Enzymol 2003, 364:173-202.

29. Al-Dhaheri M, Rowan B: Application of phosphorylation sitespecific antibodies to measure nuclear receptor signaling: characterization of novel phosphoantibodies for estrogen receptor a. Nuclear Receptor Signaling 2006, 4:e007.

30. Brunner N, Frandsen TL, Holst-Hansen C, Bei M, Thompson EW, Wakeling AE, et al.: MCF7/LCC2: a 4-hydroxytamoxifen resistant human breast cancer variant that retains sensitivity to the steroidal antiestrogen ICI 182,780. Cancer Res 1993, 53:3229-3232.

31. Barkhem T, Haldosen LA, Gustafsson JA, Nilsson S: pS2 Gene expression in HepG2 cells: complex regulation through crosstalk between the estrogen receptor alpha, an estrogenresponsive element, and the activator protein I response element. Mol Pharmacol 2002, 61:1273-1283.

32. Berry M, Nunez AM, Chambon P: Estrogen-responsive element of the human pS2 gene is an imperfectly palindromic sequence. Proc Natl Acad Sci USA 1989, 86: 1218-1222.

33. Barkhem T, Haldosen LA, Gustafsson JA, Nilsson S: Transcriptional Synergism on the pS2 Gene Promoter between a pl60 Coactivator and Estrogen Receptor-alpha Depends on the Coactivator Subtype, the Type of Estrogen Response Element, and the Promoter Context. Mol Endocrinol 2002, 16:257I-258I.

34. Munstermann U, Fritz G, Seitz G, Lu YP, Schneider HR, Issinger OG Casein kinase II is elevated in solid human tumours and rapidly proliferating non-neoplastic tissue. Eur J Biochem 1990, I 89:25I-257.

35. Weigel NL, Moore NL: Steroid receptor phosphorylation: a key modulator of multiple receptor functions. Mol Endocrinol 2007, 2I:23II-23I9.

36. Nichols M, Rientjes JJ, Stewart AF: Different positioning of the ligand-binding domain helix $I 2$ and the $F$ domain of the estrogen receptor accounts for functional differences between agonists and antagonists. EMBO J 1998, 17:765-773

37. Montano MM, Muller V, Trobaugh A, Katzenellenbogen BS: The carboxy-terminal $F$ domain of the human estrogen receptor: role in the transcriptional activity of the receptor and the effectiveness of antiestrogens as estrogen antagonists. Mol Endocrinol 1995, 9:8|4-825.

38. Schwartz JA, Zhong L, Deighton-Collins S, Zhao C, Skafar DF: Mutations targeted to a predicted helix in the extreme carboxyterminal region of the human estrogen receptor-alpha alter its response to estradiol and 4-hydroxytamoxifen. $\mathrm{Jiol}$ Chem 2002, I5:13202-13209.

39. Koide A, Zhao C, Naganuma M, Abrams J, Deighton-Collins S, Skafar $D F$, et al.: Identification of regions within the $\mathbf{F}$ domain of the human estrogen receptor-alpha important for modulating transactivation and protein-protein interactions. Mol Endocrinol 2007, 4:829-842.

40. Delage-Mourroux R, Martini PG, Choi I, Kraichely DM, Hoeksema J, Katzenellenbogen BS: Analysis of estrogen receptor interaction with a repressor of estrogen receptor activity (REA) and the regulation of estrogen receptor transcriptional activity by REA. I Biol Chem 2000, 46:35848-35856.

4I. Lahooti $\mathrm{H}$, Thorsen T, Aakvaag A: Modulation of mouse estrogen receptor transcriptional activity by protein kinase $c$ delta. Journal of Molecular Endocrinology 1998, 20:245-259.

42. Tzeng DZ, Klinge CM: Phosphorylation of purified estradiol-liganded estrogen receptor by casein kinase II increases estrogen response element binding but does not alter ligand stability. Biochemical \& Biophysical Research Communications 1996, 223:554-560.

43. Landesman-Bollag E, Romieu-Mourez R, Song DH, Sonenshein GE, Cardiff RD, Seldin DC: Protein kinase CK2 in mammary gland tumorigenesis. Oncogene 200I, 20:3247-3257. 
44. Yde CW, Frogne T, Lykkesfeldt AE, Fichtner I, Issinger OG, Stenvang $\mathrm{J}$ : Induction of cell death in antiestrogen resistant human breast cancer cells by the protein kinase CK2 inhibitor DMAT. Cancer Lett 2007, 256:229-237.

45. Zhou ZX, Kemppainen JA, Wilson EM: Identification of three proline-directed phosphorylation sites in the human androgen receptor. Mol Endocrinol 1995, 9:605-615.

46. Gioeli D, Black BE, Gordon V, Spencer A, Kesler CT, Eblen ST, et al:: Stress kinase signaling regulates androgen receptor phosphorylation, transcription, and localization. Mol Endocrinol 2006, 20:503-515.

47. Knotts TA, Orkiszewski RS, Cook RG, Edwards DP, Weigel NL: Identification of a phosphorylation site in the hinge region of human progesterone receptor and additional amino terminal phosphorylation sites. J Biol Chem 2000, I I:8475-8483.

48. Ahmed K, Gerber DA, Cochet C: Joining the cell survival squad: an emerging role for protein kinase CK2. Trends Cell Biol 2002, 1 2:226-230.

49. Bai W, Rowan BG, Allgood VE, O'Malley BW, Weigel NL: Differential phosphorylation of chicken progesterone receptor in hormone-dependent and ligand-independent activation. J Biol Chem 1997, 272:10457-10463.

50. Rowan BG, Garrison N, Weigel NL, O'Malley BW: 8-Bromo-cyclic AMP induces phosphorylation of two sites in SRC-I that facilitate ligand-independent activation of the chicken progesterone receptor and are critical for functional cooperation between SRC-I and CREB binding protein. Mol Cell Biol 2000, 20:8720-8730.

5I. Rowan BG, Weigel NL: Analysis of Steroid/Nuclear Receptor Phosphorylation. In The Nuclear Receptor Superfamily, A Practical Approach Edited by: Picard D. Oxford, UK: Oxford University Press; 1999.

52. Bai W, Weigel NL: Phosphorylation and steroid hormone action. [Review] [II5 refs]. Vitamins \& Hormones 1995, 5 I:289-313.

53. Landesman-Bollag E, Channavajhala PL, Cardiff RD, Seldin DC: p53 deficiency and misexpression of protein kinase CK2alpha collaborate in the development of thymic lymphomas in mice. Oncogene 1998, 16:2965-2974.

Publish with Bio Med Central and every scientist can read your work free of charge

"BioMed Central will be the most significant development for disseminating the results of biomedical research in our lifetime. "

Sir Paul Nurse, Cancer Research UK

Your research papers will be:

- available free of charge to the entire biomedical community

- peer reviewed and published immediately upon acceptance

- cited in PubMed and archived on PubMed Central

- yours - you keep the copyright
BioMedcentral 